\title{
Potential of Portuguese vine shoot wastes as natural resources of bioactive compounds
}

\author{
Manuela M. Moreira ${ }^{\text {a,* }}$, M. Fátima Barroso a , João Vasconcellos Porto ${ }^{\mathrm{b}}$, M.J. Ramalhosa ${ }^{\text {a }}$, Jaroslava Švarc-Gajić ${ }^{\mathrm{c}}$, \\ Letícia Estevinho $^{\mathrm{d}, \mathrm{e}}$, Simone Morais ${ }^{\mathrm{a}}$, Cristina Delerue-Matos ${ }^{\mathrm{a}}$ \\ a REQUIMTE/LAQV, Instituto Superior de Engenharia do Instituto Politécnico do Porto, Rua Dr. António Bernardino de Almeida, 431, 4249-015 Porto, Portugal \\ b Sogrape Vinhos, S.A., Aldeia Nova, 4430-809 Avintes, Portugal \\ c Faculty of Technology, University of Novi Sad, Bulevar cara Lazara 1, 21000 Novi Sad, Serbia \\ d Agricultural College of Bragança Polytechnic Institute of Bragança, Bragança, Portugal \\ e IBB - Institute for Biotechnology and Bioengineering, Centre of Biological Engineering, Universidade do Minho, Braga, Portugal
}

\section{H I G H L I G H T S}

- Phenolic, antioxidant and biological activities of vine shoots were examined.

- Subcritical-water, microwave-assisted and conventional extractions were employed.

- Tinta Roriz has higher phenolic and antioxidant activity than Touriga Nacional.

- The tested vine shoot extracts inhibited $\alpha$-amylase and acetylcholinesterase enzymes.

- Vine shoot extracts had activity against S. mitis, E. coli and C. albicans.

\section{A R T I C L E I N F O}

\section{Article history:}

Received 6 February 2018

Received in revised form 3 April 2018

Accepted 4 April 2018

Available online 10 April 2018

Editor: Frederic Coulon

\section{Keywords:}

Vine shoots

Antioxidant activity

HPLC-PDA analysis

Polyphenols

\section{G R A P H I C A L A B S T RACT}

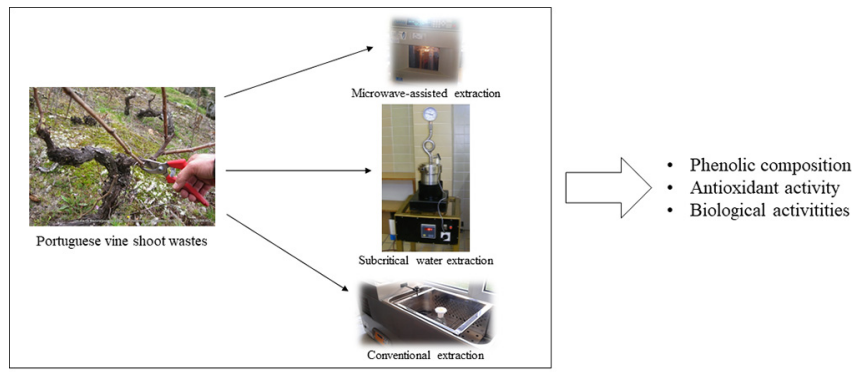

Valorization of vine shoots through the extraction of bioactive compounds to obtain high added value products

Abbreviations: AA, ascorbic acid; AAPH, 2,2'-azobis-2-amidinopropane; ATCC, American Type Culture Collection; CE, conventional extraction; CFU, colony forming units; DPPH-RSA,

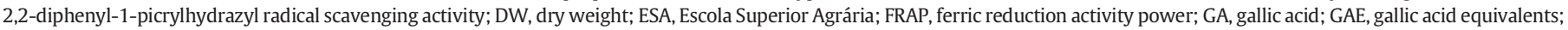

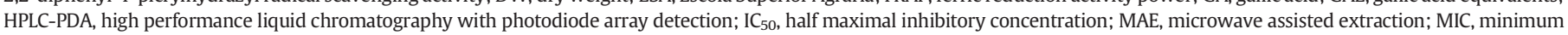

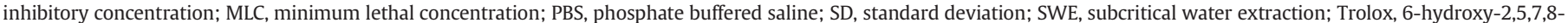
tetramethylchroman-2-carboxilic acid; TE, trolox equivalents; TPC, total phenolic content; TPTZ, 2,4,6-tris(2-pyridyl)-s-triazine; UAE, ultrasound assisted extraction.

* Corresponding author at: REQUIMTE, Instituto Superior de Engenharia do Porto, Instituto Politécnico do Porto, Rua Dr. António Bernardino de Almeida, 431, 4200-072 Porto, Portugal.

E-mail address: manuela.moreira@graq.isep.ipp.pt. (M.M. Moreira). 
Bioactive compounds Antimicrobial activity compounds, with gallic acid, catechin, myricetin and kaempferol-3-O-rutinoside being the main contributors to the phenolic composition. Portuguese vine shoot wastes could serve as easily accessible source of natural antioxidants for the food or pharmaceutical industries.

(C) 2018 Elsevier B.V. All rights reserved.

\section{Introduction}

One of the most important economic activities in Portugal is the cultivation of Vitis (Vitaceae) grape varieties. According to the International Organization of Vine and Wine, in 2014 the Portuguese vitiviniculture area cultivated was 221,448 ha and the grape production was 8,185,120 tons (Wine, 2017). During the harvest season, this wineproducing results in a huge amount of vineyard wastes, especially vine shoots, which could be re-used in valued added applications, as their present economic value is nearly nule (Delgado de la Torre et al., 2012; Gullón et al., 2018; Hagemann et al., 2018; Sánchez-Gómez et al., 2016). Currently, they are incorporated in the soil, which enables the biodegradation of the vegetal matter reducing the need for application of organic correctives and/or fertilizers (Hagemann et al., 2018). However, using this waste as a natural resource of bioactive compounds could increase its economic value (Delgado-Torre et al., 2012; Karacabey et al., 2012; Sánchez-Gómez et al., 2014; Teixeira et al., 2014).

Vine shoots have been shown to be a rich source of bioactive compounds, including phenolic compounds, which content depends on several factors such as grapevine variety, age, growth conditions, among others (Figueiredo-González et al., 2012a; Gullón et al., 2018; LuqueRodríguez et al., 2006; Pérez-Lamela et al., 2007; Rajha et al., 2014c). Additionally, experimental conditions, such as temperature, time, and solvent composition, also affect the yield of phenolic compounds recovered (Figueiredo-González et al., 2013; Figueiredo-González et al., 2012b; Figueiredo-González et al., 2012c; Karacabey and Mazza, 2010; Karacabey et al., 2012).

Luque-Rodríguez et al. (2006) were the pioneers to investigate the extraction of polyphenols from vine shoots of Vitis vinifera by superheated ethanol-water mixtures. Although, as can be seen from the analysis of Table 1, which summarizes the collected data from the literature regarding the phenolic compounds extraction from vine shoots, only in the last 7 years higher efforts have been made in the exploitation of this vineyard waste as a potential source of phenolic compounds. The majority of the reported studies uses aqueous ethanol for phenolics extraction from vine byproducts (Alexandru et al., 2014; Çetin et al., 2011; Delgado-Torre et al., 2012; Farhadi et al., 2016; Ju et al., 2016; Karacabey et al., 2012; Luque-Rodríguez et al., 2006). In some cases (Rajha et al., 2015a; Sánchez-Gómez et al., 2014; Sánchez-Gómez et al., 2016), water was employed as extracting solvent, but the total phenolic content (TPC) reported was lower than the obtained employing mixtures with organic solvents (Delgado-Torre et al., 2012; Rajha et al., 2015a; Sánchez-Gómez et al., 2014).

Regarding the extraction techniques employed, conventional extraction (CE) is the preferred method for the recovery of polyphenols from vine wastes (Alexandru et al., 2014; Çetin et al., 2011; Gullón et al., 2017; Ju et al., 2016; Karacabey and Mazza, 2010; Rajha et al., 2015b; Sánchez-Gómez et al., 2014). Recently, the use of auxiliary energies, such as microwaves and ultrasound, has enhanced the extraction process, as well as the yield of recovered compounds (Alexandru et al., 2014; Delgado-Torre et al., 2012; Farhadi et al., 2016; Sánchez-Gómez et al., 2014). Despite of being under exploitation, another environmentalfriendly extraction technique that is gaining considerable attention for polyphenols recovery is subcritical water extraction (SWE) (Aliakbarian et al., 2012; Plaza et al., 2010). As far as we know, only one study has been conducted using a pressurized low-polarity water extractor to recover trans-resveratrol and trans- $\varepsilon$-viniferin compounds from vine shoot wastes (Karacabey et al., 2012).
This study represents the first attempt to characterize the phenolic profile and antioxidant activity, as well as the biological activities from two important Portuguese vine shoot varieties (Touriga Nacional, TN and Tinta Roriz, TR) from Dão region (North Center of Portugal) for the potential utilization of these wastes as a source of natural bioactive compounds. For that, the efficiency of three extraction techniques (SWE, microwave-assisted extraction (MAE), and CE) for the recovery of bioactive compounds from vine shoots was evaluated. The obtained vine shoot extracts were characterized in terms of total phenolic and flavonoid content, and antioxidant activity by Ferric Reducing Activity Power (FRAP), 2,2-diphenyl-picrylhydrazyl radical scavenging activity (DPPH-RSA) and anti-hemolytic assays. The $\alpha$-amylase and acetylcholinesterase inhibition and the antimicrobial activities, as well as the phenolic profile by high-performance liquid chromatography (HPLC) analysis were also determined.

\section{Materials and methods}

\subsection{Chemicals}

Sodium carbonate ( $\geq 99 \%$ ), Folin's phenol reagent, and gallic acid (GA, $\geq 98 \%$ ) were used in the Folin-Ciocalteu assay and were obtained from Sigma-Aldrich (Madrid, Spain). DPPH radical, TPTZ (2,4,6-Tris(2pyridyl)-s-triazine, 99\%), aluminium chloride hexahydrate (99\%) and 6-hydroxy-2,5,7,8-tetramethylchromane-2-carboxylic acid (Trolox, 98\%) were also from Sigma. Absolute anhydrous ethanol (p.a.), sodium nitrite ( $\geq 97 \%$ ) and ascorbic acid (AA, 99.7\%) were acquired from Carlo Erba (Peypin, France), Merck and Riedel-de Haën, respectively. Methanol and formic acid for HPLC analysis were gradient grade and got from Merck (Darmstadt, Germany). Phenolic compound standards were bought to Sigma-Aldrich (Madrid, Spain). Other chemicals were from Sigma (Madrid, Spain) and analytical grade.

\subsection{Samples collection and preparation}

Vine shoots from two different $V$. vinifera varieties (TN and TR) were kindly provided by Sogrape Vinhos, S. A. (Portugal). Vine shoots were sampled in Quinta dos Carvalhais, located in Mangualde (North of Portugal), in November of 2015 by randomized selection. The moisture content of each vine shoot variety was determined using a Moisture Analyser (Kern MLS 50-3IR160) and was $13.4 \pm 0.7$ and $12.8 \pm 0.9 \%$ for TN and TR, respectively. After oven-drying (Model no. 2000208, J.P. Selecta, Barcelona, Spain) the vine shoots at $50{ }^{\circ} \mathrm{C}$ for $24 \mathrm{~h}$, they were milled (Retsch ZM200) to a particle size smaller than $1 \mathrm{~mm}$ and stored in sealed bags at room temperature until use.

\subsection{Extraction of phenolic compounds}

\subsubsection{Microwave-assisted extraction}

MAE was carried out in a MARS-X $1500 \mathrm{~W}$ (Microwave Accelerated Reaction System for Extraction and Digestion, CEM, Mathews, NC, USA) using the conditions previously optimized by Moreira et al. (2017). Milled dried vine shoots $(0.1 \mathrm{~g})$ were extracted with $20 \mathrm{~mL}$ ethanol: water $60: 40 \mathrm{v} / \mathrm{v}$ during $20 \mathrm{~min}$ at $100{ }^{\circ} \mathrm{C}$. The obtained extract was centrifugated (Heraeus ${ }^{\mathrm{TM}}$ Megafuge ${ }^{\mathrm{TM}}$ 16R Centrifuge, Thermo Scientific) for $10 \mathrm{~min}$ at $4000 \mathrm{rpm}$, and the supernatant was stored at $-20^{\circ} \mathrm{C}$ until further analysis. 
Table 1

Summary of the published reports on the extraction of phenolic compounds from vine shoot wastes.

\begin{tabular}{|c|c|c|c|c|}
\hline Vine shoot variety & Extraction technique and conditions & Assay & Units & Reference \\
\hline $\begin{array}{l}\text { Manzanares (Ciudad Real, } \\
\text { Spain) }\end{array}$ & $\begin{array}{l}\text { SHLE }{ }^{\mathrm{a}}: 1 \mathrm{~g} \text {, ethanol:water } 80: 20 \mathrm{v} / \mathrm{v} \text { at } \mathrm{pH} 3,60 \mathrm{~min}, 240^{\circ} \mathrm{C} \text {, } \\
100 \mathrm{bar} \\
\mathrm{CE}^{\mathrm{b}}: 3 \mathrm{~g}, 45 \mathrm{~mL} \text { ethanol:water } 80: 20 \mathrm{v} / \mathrm{v} \text { at } \mathrm{pH} 3,24 \mathrm{~h}, 25^{\circ} \mathrm{C}\end{array}$ & $\mathrm{TPC}^{\mathrm{c}}: 38$ & $\begin{array}{l}\mathrm{mg} \mathrm{GAE} / \mathrm{g} \\
\mathrm{DW}^{\mathrm{e}}\end{array}$ & $\begin{array}{l}\text { Luque-Rodríguez } \\
\text { et al. (2006) }\end{array}$ \\
\hline Pinot noir $V$. vinifera & $\mathrm{CE}: 1 \mathrm{~g}, 70 \mathrm{~mL}$ of aqueous ethanol $58 \%, 83.6^{\circ} \mathrm{C}$ & TPC: 8.91 & $\begin{array}{l}\mathrm{mg} \\
\text { resveratrol/g } \\
\text { DW }\end{array}$ & $\begin{array}{l}\text { Karacabey and } \\
\text { Mazza (2010) }\end{array}$ \\
\hline Locally collected in Spain & Alkaline hydrolysis: $12 \% \mathrm{NaOH}, 120 \mathrm{~min}, 130{ }^{\circ} \mathrm{C}$ & TPC: 4524.5 & $\mathrm{mg} / \mathrm{L}$ & Max et al. (2010) \\
\hline $\begin{array}{l}10 \text { different vineyards from } \\
\text { Süleyman Demirel University } \\
\text { (Isparta, Turkey) }\end{array}$ & $\begin{array}{l}\mathrm{CE}: 0.5 \mathrm{~g}, 10 \mathrm{~mL} \text { of ethanol:water } 60: 40 \mathrm{v} / \mathrm{v}, 30 \mathrm{~min}, 80^{\circ} \mathrm{C} \\
\text { with gentle stirring }\end{array}$ & TPC: $25.36 \pm 1.62$ to $36.56 \pm 2.67$ & $\begin{array}{l}\mathrm{mg} \mathrm{GAE} / \mathrm{g} \\
\mathrm{DW}\end{array}$ & $\begin{array}{l}\text { Çetin et al. } \\
\text { (2011) }\end{array}$ \\
\hline $\begin{array}{l}18 \text { different vineyard cultivars } \\
\text { from Sierra de Segura (Spain) }\end{array}$ & SHLE: $1 \mathrm{~g}$, ethanol:water $80: 20 \mathrm{v} / \mathrm{v}$ at $\mathrm{pH} 3,60 \mathrm{~min}, 180^{\circ} \mathrm{C}$ & $\begin{array}{l}\text { TPC: } 650.4 \\
\text { HPLC }{ }^{f} \text { : pyrogallol (6756), catechin (3936), } \\
\text { sinapic acid (1155) }\end{array}$ & $\begin{array}{l}\mathrm{mg} \mathrm{GAE} / \mathrm{mL} \\
\text { extract } \\
\mathrm{mg} / \mathrm{g} \mathrm{DW}\end{array}$ & $\begin{array}{l}\text { Delgado-Torre } \\
\text { et al. }(2012)\end{array}$ \\
\hline & $\begin{array}{l}\text { MAE }^{\mathrm{g}}: 1 \mathrm{~g}, 20 \mathrm{~mL} \text { ethanol:water } 80: 20 \mathrm{v} / \mathrm{v} \text { at } \mathrm{pH} 3,5 \mathrm{~min} \text {, } \\
140 \mathrm{~W} \\
\mathrm{UAE}^{\mathrm{h}}: 1 \mathrm{~g}, 20 \mathrm{~mL} \text { ethanol:water } 80: 20 \mathrm{v} / \mathrm{v} \text { at pH 3, } 7.5 \mathrm{~min} \\
\text { with } 50 \% \text { duty cycle, } 280 \mathrm{~W}\end{array}$ & $\begin{array}{l}\text { TPC: } 401.4 \\
\text { TPC: } 546.4\end{array}$ & $\begin{array}{l}\mathrm{mg} \mathrm{GAE} / \mathrm{mL} \\
\text { extract }\end{array}$ & \\
\hline Pinot noir $V$. vinifera & $\begin{array}{l}\text { Pressurized low-polarity water: } 10 \mathrm{~g} \text {, water at } 105^{\circ} \mathrm{C} \text {, } \\
1 \mathrm{~mL} / \mathrm{min} \text {, }\end{array}$ & TPC: $4.97 \pm 0.74$ & $\mathrm{mg} / \mathrm{g}$ DW & $\begin{array}{l}\text { Karacabey et al. } \\
\text { (2012) }\end{array}$ \\
\hline $\begin{array}{l}\text { Nebbiolo (Castiglione Falletto, } \\
\text { Cueno, Italy) }\end{array}$ & $\begin{array}{l}\text { CE: sample/solvent ratio } 1: 10(\mathrm{w} / \mathrm{v}) \text {, ethanol, } 24 \mathrm{~h}, \mathrm{RT}^{\mathrm{i}} \\
\text { MAE: sample/solvent ratio } 1: 10(\mathrm{w} / \mathrm{v}) \text {, ethanol, } 30 \mathrm{~min} \text {, } \\
60^{\circ} \mathrm{C}, 1.5 \mathrm{~kW} \text {, nitrogen pressure } 5 \mathrm{bar} \\
\text { UAE: sample/solvent ratio } 1: 10(\mathrm{w} / \mathrm{v}) \text {, ethanol, } 30 \mathrm{~min}, 80 \mathrm{~W}\end{array}$ & $\begin{array}{l}<50 \\
\sim 200 \\
\sim 100\end{array}$ & $\begin{array}{l}\mathrm{mg} \mathrm{GAE} / \mathrm{g} \\
\mathrm{DW}\end{array}$ & $\begin{array}{l}\text { Alexandru et al. } \\
(2014)\end{array}$ \\
\hline Syrah, Lebanon & CE: $5 \mathrm{~g}, 50 \mathrm{~mL}$ of $1 \mathrm{~mol} / \mathrm{L} \mathrm{NaOH}, 180 \mathrm{~min}, \mathrm{RT}$ & 5.02 & $\begin{array}{l}\mathrm{mg} \mathrm{GAE} / \mathrm{g} \\
\mathrm{DW}\end{array}$ & $\begin{array}{l}\text { Rajha et al. } \\
(2014 a)\end{array}$ \\
\hline Grenache Blanc (France) & $\begin{array}{l}\text { Alkaline hydrolysis: } 15 \mathrm{~g} \text { pre-treated with } \mathrm{HVED}^{\mathrm{j}}, 300 \mathrm{~g} \text { of } \\
0.1 \mathrm{~mol} / \mathrm{L} \text { aqueous } \mathrm{NaOH}, 180 \mathrm{~min}, 50^{\circ} \mathrm{C} \text {, agitation speed } \\
160 \mathrm{rpm}\end{array}$ & 34.5 & $\begin{array}{l}\mathrm{mg} \mathrm{GAE} / \mathrm{g} \\
\mathrm{DW}\end{array}$ & $\begin{array}{l}\text { Rajha et al. } \\
\text { (2014b) }\end{array}$ \\
\hline $\begin{array}{l}\text { Airén white } V . \text { vinifera } \\
\text { (Mancha, Castilla-La Mancha } \\
\text { Spanish region) }\end{array}$ & $\begin{array}{l}\mathrm{SLDE}^{\mathrm{k}}: 200 \mathrm{~g}, 1.1 \mathrm{~L} \text { water, } 20 \text { extractive cycles of } 12 \mathrm{~min} \text {, } \\
27^{\circ} \mathrm{C}, 8 \mathrm{bar}\end{array}$ & $\begin{array}{l}\text { HPLC: flavanols }(550.81 \pm 3.46) \text {, phenolic } \\
\text { acids }(130.61 \pm 0.34) \text {, stilbenes } \\
(32.06 \pm 3.93) \text {, others }(22.11 \pm 0.32) \\
\text { HPLC: flavanols }(139.39 \pm 2.61) \text {, phenolic } \\
\text { acids }(111.10 \pm 1.05) \text {, stilbenes }(1.90 \pm 0.10) \text {, } \\
\text { others }(33.57 \pm 0.09)\end{array}$ & $\mathrm{mg} / \mathrm{kg} \mathrm{DW}$ & $\begin{array}{l}\text { Sánchez-Gómez } \\
\text { et al. (2014) }\end{array}$ \\
\hline & $\begin{array}{l}\text { MAE: } 50 \mathrm{~g}, 250 \mathrm{~mL} \text { water, } 15 \mathrm{~min}, 100^{\circ} \mathrm{C}, 600 \mathrm{~W} \\
\text { PSE }^{1}: 20 \mathrm{~g}, 100 \mathrm{~mL} \text { water, } 30 \mathrm{~min}, 100^{\circ} \mathrm{C}, 100 \mathrm{bar}\end{array}$ & Not reported & - & \\
\hline $\begin{array}{l}\text { Syrah, Tempranillo, Cabernet } \\
\text { Sauvignon, and Cabernet Franc }\end{array}$ & $\begin{array}{l}\mathrm{CE} \text { : sample/solvent ratio } 1: 20(\mathrm{w} / \mathrm{v}), 37.7 \mathrm{mg} / \mathrm{mL} \\
\text { aqueous } \beta \text {-cyclodextrin solvent, } 48 \mathrm{~h}, 66.6{ }^{\circ} \mathrm{C}\end{array}$ & $5.8-7.5$ & $\begin{array}{l}\mathrm{mg} \mathrm{GAE} / \mathrm{g} \\
\mathrm{DW}\end{array}$ & $\begin{array}{l}\text { Rajha et al. } \\
\text { (2015b) }\end{array}$ \\
\hline Grenache Blanc (France) & $\begin{array}{l}\text { CE: } 15 \mathrm{~g} \text { pre-treated with HVED }+300 \mathrm{~g} \text { water, } 50^{\circ} \mathrm{C} \text {, } \\
160 \mathrm{rpm}\end{array}$ & 12 to 50 & $\mathrm{mg} / \mathrm{L}$ & $\begin{array}{l}\text { Rajha et al. } \\
\text { (2015a) }\end{array}$ \\
\hline $\begin{array}{l}\text { Hosseini, Ghara Shira, Agh } \\
\text { Shani, Ghara Shani } \\
\text { and Ghara Ghandome from } \\
\text { West Azerbaijan }\end{array}$ & $\begin{array}{l}\text { Ultrasonication: } 1.0 \mathrm{~g}, 5 \mathrm{~mL} \text { methanol/HCl } 99 / 1(\mathrm{v} / \mathrm{v}), 20 \\
\text { min, } 25^{\circ} \mathrm{C} \text { at constant frequency of } 35 \mathrm{kHz}(350 \mathrm{~W}) \text {, and } \\
\text { then left at RT for } 30 \mathrm{~min}\end{array}$ & $\sim 200$ & $\begin{array}{l}\text { mg GAE/g } \\
\text { DW }\end{array}$ & $\begin{array}{l}\text { Farhadi et al. } \\
(2016)\end{array}$ \\
\hline $\begin{array}{l}\text { Different varieties (copy from } \\
\text { the article) }\end{array}$ & $\begin{array}{l}\text { CE: } 100 \mathrm{~g}, 1000 \mathrm{~mL} \text { of } 1 \mathrm{~mol} / \mathrm{L} \mathrm{HCl} / \mathrm{methanol} / \text { water } \\
(1: 80: 19, \mathrm{v} / \mathrm{v} / \mathrm{v}), 20 \mathrm{~min}, 4^{\circ} \mathrm{C}, 12000 \mathrm{rpm}\end{array}$ & $52.5 \pm 1.5$ to $225 \pm 7$ & $\begin{array}{l}\mathrm{mg} \mathrm{GAE} / \mathrm{g} \\
\mathrm{DW}\end{array}$ & Ju et al. (2016) \\
\hline $\begin{array}{l}\text { Airén and Moscatel (O.D. } \\
\text { Mancha, Castilla-La Mancha } \\
\text { Spanish region) }\end{array}$ & CE: $50 \mathrm{~g}, 250 \mathrm{~mL}$ water, $60 \mathrm{~min}, 100{ }^{\circ} \mathrm{C}$ & $\begin{array}{l}\text { HPLC: flavanols }(204.66 \pm 18.39) \text {, phenolic } \\
\text { acids }(100.51 \pm 2.06) \text {, stilbenes }(0.97 \pm 0.05) \text {, } \\
\text { others }(23.21 \pm 0.66)\end{array}$ & $\mathrm{mg} / \mathrm{kg} \mathrm{DW}$ & $\begin{array}{l}\text { Sánchez-Gómez } \\
\text { et al. (2016) }\end{array}$ \\
\hline $\begin{array}{l}\text { Hondarribi Zuri V. vinifera from } \\
\text { Hoiarztun, Guipúzcoa, } \\
\text { Basque Country, Spain }\end{array}$ & $\begin{array}{l}\mathrm{CE} \text { : autohydrolisis pre-treatment with water at } 215^{\circ} \mathrm{C}+ \\
\text { ethyl acetate extraction, } 15 \mathrm{~min} \text {, RT, stirring }\end{array}$ & TPC: $16.20 \pm 0.25$ & $\begin{array}{l}\text { mg GAE/g } \\
\text { DW }\end{array}$ & $\begin{array}{l}\text { Gullón et al. } \\
\text { (2017) }\end{array}$ \\
\hline $\begin{array}{l}\text { a SHLE: superheated liquid extrac } \\
\text { b CE: conventional extraction. } \\
\text { c TPC: total phenolic content. } \\
\text { d GAE: gallic acid equivalents. } \\
\text { e DW: dry weight. } \\
\text { f } \text { HPLC: high performance liquid } \\
\text { g MAE: microwave-assisted extra } \\
\text { h UAE: ultrasound assisted extrac } \\
\text { i } \text { RT: room temperature. } \\
\text { j HVED: high-voltage electrical di } \\
\text { k SLDE: solid liquid dynamic extr } \\
\text { 1 } \text { PSE: pressurize solvent extractic }\end{array}$ & $\begin{array}{l}\text { chromatography. } \\
\text { ictin. } \\
\text { tion. } \\
\text { scharge. } \\
\text { action. } \\
\text { on. }\end{array}$ & & & \\
\hline
\end{tabular}

\subsubsection{Subcritical-water extraction}

SWE was performed in a house-made batch-type extractor of the total capacity of $1.7 \mathrm{~L}$ as previously described by Švarc-Gajić et al. (2017). To avoid oxidation of phenolic compounds at high temperatures pressurization was done with 99.99\% nitrogen (Messer) through builtin valve. The batch type extractor was equipped with vibrational platform that allowed convective mass transfer during extraction and variable vibration frequencies. $5 \mathrm{~g}$ of dried vine shoots was extracted with $200 \mathrm{~mL}$ of water at $150{ }^{\circ} \mathrm{C}$ for $40 \mathrm{~min}$ at a constant pressure of 40 bars. During extraction, agitation was assured with the frequency of the vibrational platform of $3 \mathrm{~Hz}$. After extraction, cooling of the extraction vessel was done by placing it in the flow-through water bath 
at the temperature of $20^{\circ} \mathrm{C}$. After cooling, depressurization was done by valve opening. Obtained extracts were separated by filtration and stored until analysis.

\subsubsection{Conventional extraction}

$0.5 \mathrm{~g}$ of dried vine shoots were extracted with $20.0 \mathrm{~mL}$ of ethanol: water 50:50 v/v in glass Erlenmeyer flasks for $2 \mathrm{~h}$ at $55^{\circ} \mathrm{C}$ in a water bath shaker (model BSC127E, C from OVAN) at $100 \mathrm{rpm}$ as described by Moreira et al. (2017). During the extraction to avoid solvent evaporation and phenolic compounds degradation by light, the glass flasks were closed and covered with aluminium foil. Prior to analysis, the extraction mixture was centrifugated.

\subsection{Determination of total phenolic and flavonoid content}

Phenolic and flavonoid content were assessed by the spectrophotometric assays using the Folin-Ciocalteau reagent and aluminium chloride, respectively (Paz et al., 2015). Results were expressed as mg of gallic acid equivalents (GAE) per g of dry weight of sample ( $\mathrm{mg} \mathrm{GAE} / \mathrm{g}$ DW) and mg of epicatechin equivalents per $g$ dry weight of sample ( $\mathrm{mg}$ EE/g DW) for TPC and TFC assays, respectively. Each extract was analyzed in triplicate.

\subsection{High performance liquid chromatographic analysis}

Polyphenol characterization and quantification in vine shoot extracts were performed by HPLC with photodiode array (PDA) detection. Before injection, $1 \mathrm{~mL}$ from the obtained vine shoot extracts was evaporated to dryness, resuspended in $100 \mu \mathrm{L}$ of methanol:0.1\% formic acid (50:50, v/v), vortexed and filtered through a $0.22 \mu \mathrm{m}$ PTFE filter. HPLC analyses were performed with a Shimadzu HPLC system equipped with a Phenomenex Gemini $\mathrm{C}_{18}$ column $(250 \mathrm{~mm} \times 4.6 \mathrm{~mm}, 5 \mu \mathrm{m})$, using the method described by Moreira et al. (2017). Methanol (A) and water (B) both with $0.1 \%$ formic acid were used as mobile phase at a flow rate of $1.0 \mathrm{~mL} / \mathrm{min}$ and UV spectra was recorded in a range of 190 to $600 \mathrm{~nm}$. For the quantification of polyphenols, different concentrations ( 1 to $200 \mathrm{mg} / \mathrm{L}$ ) of each standard were prepared in a mixture of methanol:water $(50 / 50, \mathrm{v} / \mathrm{v})$ from the respective stock solution. The amount of individual phenolic compounds found in each extract, resulting from triplicate injections, was expressed as $\mathrm{mg} / 100 \mathrm{~g}$ of DW.

\subsection{Antioxidant activity}

\subsubsection{FRAP and DPPH-RSA assays}

The antioxidant activity of the investigated vine shoots was evaluated by the FRAP and by the DPPH-RSA assays as previously described (Paz et al., 2015).

In the FRAP assay, $180 \mu \mathrm{L}$ of the FRAP reagent $(10 \mathrm{~mL}$ of $300 \mathrm{mmol} / \mathrm{L}$ acetate buffer ( $\mathrm{pH} 3.6), 1 \mathrm{~mL}$ of $10 \mathrm{mmol} / \mathrm{L} \mathrm{TPTZ}$ in $40 \mathrm{mmol} / \mathrm{L} \mathrm{HCl}$, and $1 \mathrm{~mL}$ of $20 \mathrm{mmol} / \mathrm{L} \mathrm{FeCl}_{3}$ ) diluted to one-third with acetate buffer was added to each well, with $20 \mu \mathrm{L}$ of sample. The absorbance was measured at $593 \mathrm{~nm}$ and $37^{\circ} \mathrm{C}$, and the calibration curve was prepared with AA. The results were expressed as mg AA equivalents per g of dry weight (mg AAE/g DW) of sample.

For DPPH-RSA of the vine shoots, $25 \mu \mathrm{L}$ of sample was mixed with $200 \mu \mathrm{L}$ of DPPH* ethanolic solution $(0.04 \mathrm{mg} / \mathrm{mL})$. The mixture was left to stand for $30 \mathrm{~min}$ in the dark and the absorbance was measured at $517 \mathrm{~nm}$. The calibration curve was prepared with Trolox and the results were expressed as mg Trolox equivalents per g of dry weight ( $\mathrm{mg} \mathrm{TE} / \mathrm{g}$ DW) of sample. Each extract was analyzed in triplicate.

\subsubsection{Protective effect on AAPH-induced hemolysis}

2.6.2.1. Preparation of erythrocyte suspensions. Peripheral blood was collected from five randomly chosen sheep allocated at the School of
Agriculture of the Polytechnic Institute of Bragança. All the assays were carried out through the EU Directive 2010/63/EU (European Union, 2010) to protect the animals used for experimental and scientific purposes. Sheep were carefully examined to exclude the presence of any signs of disease. Tubes with sodium citrate were filled with the blood, centrifuged for $10 \mathrm{~min}$ at $700 \times \mathrm{g}$, and the plasma and leukocyte film were rejected. A sodium chloride $(\mathrm{NaCl})$ solution of $0.9 \%$ was used to wash three times the erythrocytes, and a $10 \%$ erythrocyte suspension was used for the inhibition assays of oxidative hemolysis performed following the described by Campos et al. (2016).

2.6.2.2. Inhibition of oxidative hemolysis. In order to evaluate the protective effect of vine shoot extracts against 2,2'-azobis-2-amidinopropane (AAPH)-induced hemolysis, the erythrocyte suspension was preincubated at $37^{\circ} \mathrm{C}$ for $30 \mathrm{~min}$ in the presence of different concentrations of extract, ranging from 10 to $60 \mu \mathrm{g}$ extract $/ \mathrm{mL}$. Afterwards, $50 \mathrm{mM}$ AAPH aqueous solution was added to the vine shoot extracts subjected to hemolysis induction. This mixture was shaken gently during incubation at $37^{\circ} \mathrm{C}$ for $4 \mathrm{~h}$. A negative control (erythrocytes in a phosphate buffered saline (PBS) of $150 \mathrm{mmol} / \mathrm{L} \mathrm{NaCl}, 1.9 \mathrm{mmol} / \mathrm{L} \mathrm{NaH}_{2} \mathrm{PO}_{4}$, $8.1 \mathrm{mmol} / \mathrm{L} \mathrm{Na}_{2} \mathrm{HPO}_{4}, \mathrm{pH} 7.4$ ) and extract controls (erythrocytes in PBS with each vine shoot extract) were used for comparison in all experiments. The inhibition of oxidative hemolysis was accessed by a colorimetric assay as described by Valente et al. (2011). For that, at every hour an aliquot of the reaction mixture was diluted with $0.9 \% \mathrm{NaCl}$ solution and centrifuged for $10 \mathrm{~min}$ at $700 \times \mathrm{g}$, enabling the separation of the erythrocytes. The hemolysis percentage was determined with the formula $A / B \times 100$, being $A$ the absorbance of the sample at $545 \mathrm{~nm}$ and $B$ the absorbance of the distilled water after the complete hemolysis. The half maximal inhibitory concentration $\left(\mathrm{IC}_{50}\right)$ after $3 \mathrm{~h}$ was determined from the plot of hemolysis percentage against the concentration of vine shoot extract. Assays were performed in triplicate, and AA was used as the control.

\subsection{Acetylcholinesterase inhibition assay}

Inhibition of acetylcholinesterase was evaluated spectrophotometrically following the method developed by Ellman et al. (1961) with slight modifications (Sukumaran et al., 2016). Acetylcholinesterase of Electrophorus electricus (electric eel Type-VI-S, Sigma Chemical Co, St. St. Louis, MO, USA) was used as substrate. The acetylcholinesterase activity was quantified using $15 \mathrm{mM}$ 5,5'-dithiobis-(2-nitrobenzoic acid) (DTNB, Sigma Chemical Co, St. St. Louis, MO, USA). The hydrolysis of acetylcholine iodide was monitored though the formation of the anion 5tio-2-methyl nitrobenzoate (with yellow color) at $412 \mathrm{~nm}$ for $15 \mathrm{~min}$ that results from the reaction of DTNB with thiocholines. The inhibition percentage was determined by comparing the rates of reaction of vine shoot extracts (final concentrations of 1.5, 10, 50, 250, 500, 750 and $1000 \mu \mathrm{g} / \mathrm{mL}$ ) with those of the blank (ethanol in phosphate buffer $0.2 \mathrm{M}, \mathrm{pH}=8)$ through the expression $(E-S) / E \times 100$, where $E$ is the enzyme activity without the extract and $S$ is the enzyme activity of vine shoot extract. $\mathrm{IC}_{50}$ values were estimated from the graphic of inhibition percentage versus vine shoot extract concentration. Assays were performed in triplicate, and eserine was used as the control.

\section{8. $\alpha$-Amylase inhibition assay}

Evaluation of $\alpha$-amylase inhibition was performed as reported by Thilagam et al. (2013). Starch azure (Sigma Chemical Co, St. St. Louis, MO, USA) was used as substrate and $2 \mathrm{mg}$ were dissolved in buffer Tris $50 \mathrm{mM}-\mathrm{HCl}$ (Merck, Darmstadt, Germany) ( $\mathrm{pH} \mathrm{6.9)}$ containing $10 \mathrm{mM} \mathrm{CaCl}_{2}$ (Merck, Darmstadt, Germany). The mixture was then boiled at $100{ }^{\circ} \mathrm{C}$ during $5 \mathrm{~min}$ and incubated at $37^{\circ} \mathrm{C}$ for $10 \mathrm{~min}$. The vine shoot extracts were then dissolved in DMSO (50\%) at final concentrations of $10,50,250,500,750,1000$ and $1250 \mu \mathrm{g} / \mathrm{mL}$ and $0.1 \mathrm{~mL}$ of $\alpha$ amylase from pig (Sigma, A-6255; $2.0 \mathrm{U} / \mathrm{mL} ; 50 \mathrm{mM}$ Tri- $\mathrm{HCl}$ buffer 
containing $10 \mathrm{mM} \mathrm{CaCl}_{2}$, pH 6.9) was added. The mixture was incubated at $37^{\circ} \mathrm{C}$ for $10 \mathrm{~min}$ and the reaction was stopped by adding $0.5 \mathrm{~mL}$ of $50 \%$ acetic acid. Afterwards, this mixture was centrifuged (5 min, $2000 \mathrm{rpm}$ ), and the supernatant absorbance was measured at $595 \mathrm{~nm}$. $\alpha$-Amylase inhibition percentage was estimated from the expression: $100-((B-b) /(A-a)) \times 100$ where $A$ is the activity without inhibitor, a represents the negative control without inhibitor, $B$ is the activity with inhibitor and $\mathrm{b}$ is the negative control with inhibitor. The extract concentration providing $50 \%$ inhibition ( $\mathrm{IC}_{50}$ ) was calculated by interpolation from the graph of $\alpha$-amylase inhibition percentage against extract concentration. All the reactions were performed in triplicate, and acarbose was used as positive control.

\subsection{Antimicrobial activity}

The minimum inhibitory concentration (MIC) is defined as the lowest concentration of extract necessary to inhibit microbial growth. The lowest extract concentration at which reduction of initial bacterial or fungal count was $99.9 \%$ was considered to be minimum lethal concentration (MLC). MIC and MLC of vine shoot extracts, as well as the controls, gentamicin (antibiotic) and amphotericin B (antifungal) were determined against Gram-negative bacteria (Escherichia coli ATCC $29998^{\mathrm{TM}}$ and Escherichia coli ESA37 Cephalosporins-resistant), Grampositive bacteria (Streptococcus mitis ATCC $® 494565^{\mathrm{TM}}$ and $\beta$-Lactam Resistance Streptococcus mitis ESA65), and the yeasts Candida albicans ATCC $10231^{\mathrm{TM}}$ and amphotericin B-resistant C. albicans ESA 100. All microorganisms used were certified by the American Type Culture Collection (ATCC) and the Agricultural School (Escola Superior Agrária, ESA) of Bragança, Portugal.

The in vitro antimicrobial activity was evaluated through broth microdilution assay in 96 multi-well microtiter plates, as recommended by the Clinical and Laboratory Standards Institute (CLSI) Guidelines (Institute, C. A. L. S, 2012, Institute, 2014). Cell mass was properly diluted with $0.85 \% \mathrm{NaCl}$ solution to reach 0.5 on the MacFarland scale, which was checked at $580 \mathrm{~nm}$ for bacteria and $640 \mathrm{~nm}$ for yeast. The broths used were Muller-Hinton broth for bacteria or Yeasts Peptone Dextrose broth for yeast. The extracts were dissolved in dimethyl sulfoxide (DMSO, 10\%) to a final concentration of $50 \mathrm{mg} / \mathrm{mL}$. Samples diluted with broth to reach a concentration ranging from 5 to $30 \mathrm{mg} / \mathrm{mL}$ were analyzed individually with the strains.

To all wells from the plates it was added the cell mass previously prepared $\left(10^{6}\right.$ Colony Forming Units (CFU)/mL) and incubated at 37 ${ }^{\circ} \mathrm{C}$ for $24 \mathrm{~h}$ and at $25{ }^{\circ} \mathrm{C}$ for $48 \mathrm{~h}$ for bacteria and yeast, respectively. Then, the antimicrobial activity was determined by the addition of 20 $\mu \mathrm{L}$ of 2,3,5-triphenyl-2H-tetrazoliumchloride (TTC, $5 \mathrm{mg} / \mathrm{mL}$ ) solution. The antibacterial and antifungal controls used were gentamicin and amphotericin, respectively. In each assay, a negative control (containing only broth), a positive control (inoculated broth) and a DMSO control (DMSO with inoculated broth) were also employed.

To determine the MLC, $20 \mu \mathrm{L}$ of the last well where growth was observed and from the well where no color changes were noticed were mixed in broth and then incubated. The MLC was the lowest concentration that did not result in growth $(<10 \mathrm{CFU} /$ plate $)$ after this process. All the assays were performed in triplicate and results were expressed in $\mathrm{mg} / \mathrm{mL}$.

\subsection{Statistical analysis}

Statistical comparisons were made using the nonparametric Kruskal-Wallis one-way ANOVA (k samples) (IBM SPSS Statistics 20) to detect differences between the extraction techniques or vine shoot varieties in terms of TPC, TFC, FRAP and DPPH-RSA assays. In the biological activity assays, comparisons were made by one-way ANOVA followed by Tukey test. Statistical significance was defined as $p<0.05$.

\section{Results and discussion}

\subsection{Total phenolic and flavonoid content}

The TPC and the TFC of Portuguese vine shoot extracts from Dão region (North Center of Portugal) obtained using the three different extraction techniques, namely MAE, SWE and CE, are shown in Fig. 1. For both vine shoot varieties, highest significant TPC values were obtained with the more environmental-friendly extraction techniques, MAE $(21.2 \pm 1.0$ and $32.1 \pm 0.9 \mathrm{mg}$ GAE$/ \mathrm{g}$ DW for TN and TR varieties, respectively) and SWE $(22.5 \pm 1.8$ and $31.9 \pm 1.6 \mathrm{mg} \mathrm{GAE} / \mathrm{g}$ DW for TN and TR varieties, respectively). Similarly, for TFC, the maximum yield was achieved in SWE, namely in the vine shoot extract from TR (18.7 $\pm 1.2 \mathrm{mg} \mathrm{EE} / \mathrm{g} \mathrm{DW}$ ). These differences within the tested techniques could be related with the principle behind each extraction employed. In the present study, SWE was used to take advantage from water properties in superheated state, while with MAE benefits arise from the assistance of auxiliary energy to enhance the leaching process (Karacabey et al., 2012; Teixeira et al., 2014). Compared to the CE, these novel and green extraction techniques have the advantage of broken more easily the cellular structure of samples containing phenolic compounds releasing these compounds to the extracellular medium and dissolving them in the used solvents (Teixeira et al., 2014). Therefore, it was expected that MAE and SWE extracts promoted higher levels of phenolic and flavonoid compounds compared to the CE extracts. According to our knowledge, only two reports concerning the comparison of modern techniques with $\mathrm{CE}$ for polyphenols recovery from vine shoots were found (Alexandru et al., 2014; Luque-Rodríguez et al., 2006). Luque-Rodríguez et al. (2006) compared the efficiency of superheated ethanol-water mixtures with $\mathrm{CE}$, reporting a 5-fold increase in the TPC of vine shoot from Manzanares (Ciudad Real, Spain). In another study, Alexandru et al. (2014) also described that the use of nonconventional methods, namely ultrasound assisted extraction (UAE) and MAE, enabled to obtain at least 2-fold more polyphenols than CE.

Concerning the differences between the samples (Fig. 1), vine shoot from TR variety has at least 1.5-fold more polyphenols than TN. For TFC, significant differences $(p<0.05)$ between the two varieties studied were also achieved, although TN was richer in flavonoids than TR variety. To the best of our knowledge, no studies were found for these vine shoot varieties, although some authors have investigated these grape and wines varieties (Jordão and Correia, 2012; Silva and Queiroz, 2016).Jordão and Correia (2012) characterized the relationship between antioxidant capacity and anthocyanin and proanthocyanidin content of seeds and skins from these two Portuguese red grape varieties (TN and TR). Despite of the products studied being different, the results obtained for TPC agreed with ours, with TR variety presenting higher amount than TN (60.7 and $45.4 \mathrm{mg} / \mathrm{L}$, respectively), while the highest anthocyanin content, a class of phenolic compounds belonging to the flavonoid family, was also reported for TN $(112.5 \mathrm{mg} / 100 \mathrm{~g}$ berry). Silva and Queiroz (2016) also evaluated the phenolic profile from five red grapes from Dão region, including the TN and TR varieties. Their results showed that TN has 2 times more flavonoids, namely anthocyanins, than TR variety (5336.3 and $2603.0 \mathrm{mg} / \mathrm{kg}$ of lyophilized sample, respectively), which is also in accordance with our findings. Despite the reported results being from grapes, their content may be a result of the nutrients and bioactive compounds absorbed from the vine shoots. Therefore, it's not surprising that the present results are in accordance with the obtained by these authors (Jordão and Correia, 2012, Silva and Queiroz, 2016). As TN and TR vineyards pruning wastes presented identical climatic and geographical factors, viticultural characteristics and employed the same cultivation techniques, it can be concluded that any differences between the TPC and TFC may be attributed to the vine shoot variety studied.

The findings on TPC detected by the Folin-Ciocalteu assay in the analyzed extracts should be carefully compared with the data available in the literature, bearing in mind the differences between the vine shoot 
A

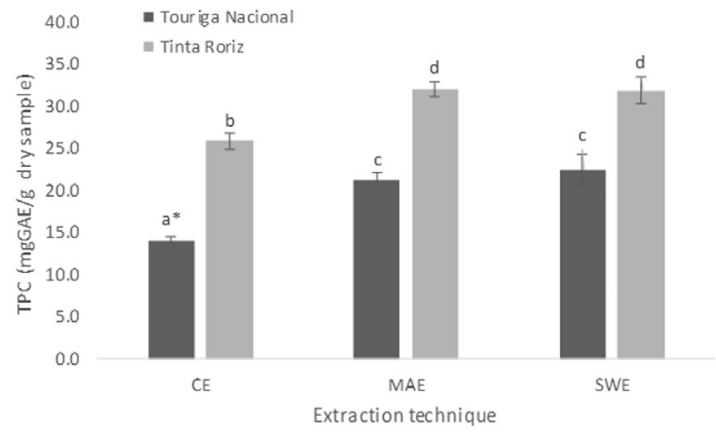

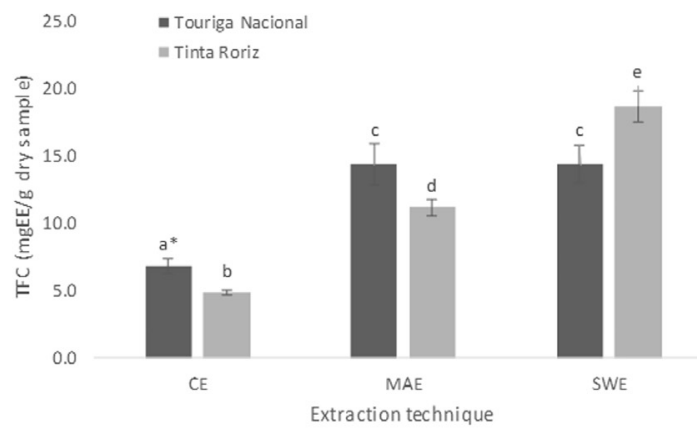

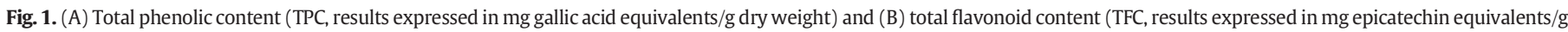

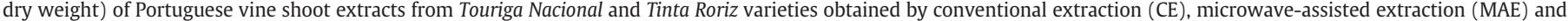

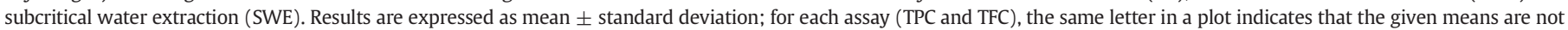
statistically significant $(p>0.05)$.

varieties and in the experimental conditions. As it can be seen in Table 1, different amounts of phenolic compounds can be extracted from vine shoot from different varieties with similar extraction techniques. In fact, the collected data (Table 1) enable to conclude that the most important factor in the recovery of phenolic compounds is the characterized vine shoot variety. In a previous study, Çetin et al. (2011) investigated the chemical composition of vine shoots from ten different cultivars from the experimental vineyard of Süleyman Demirel University (Isparta, Turkey) after applying a CE very similar to the one applied in the present study (CE conditions: $0.5 \mathrm{~g}$ sample, $10 \mathrm{~mL}$ of $60: 40$ ethanol:water, $30 \mathrm{~min}$ at $80^{\circ} \mathrm{C}$ with stirring). The reported TPC ranged from $25.36 \pm 1.62$ to $36.56 \pm 2.67 \mathrm{mg} \mathrm{GAE} / \mathrm{g} \mathrm{DW}$, also demonstrating the influence of vine shoot variety in the amount of extracted phenolic compounds. Recently, Rajha and co-workers have focused their effort on the search of green extraction techniques for the recovery of phenolic compounds from vine shoot wastes (Rajha et al., 2014a, b, 2015a, b). According to their published studies, a significant enhancement of polyphenol extraction was reported for vine shoots pre-treated with highvoltage electrical discharge, before applying the alkaline hydrolysis (TPC: 34.5 mg GAE/g DW) (Rajha et al., 2014b). Although the proposed methodology demonstrated the advantage of a pre-treatment with electrical discharges for the extraction of polyphenols, the obtained TPC was in agreement with the values reported in the present study with the environmental-friendly extraction techniques, MAE and SWE, which are less time and energy consuming than the extraction method proposed by Rajha et al. (2014b).

\subsection{Identification of individual phenolic compounds by HPLC-PDA}

The identification and quantification of phenolic compounds in vine shoot extracts obtained by the three tested extraction techniques were determined by HPLC-PDA and data are presented in Table 2.

One of the most characteristic phenolic acids found in the vine shoot extracts from both studied varieties was GA, a product from the hydrolysis of ellagitannins, which contributes to the characteristic astringency of wines (Delgado-Torre et al., 2012; Quijada-Morín et al., 2012; Sánchez-Gómez et al., 2014). GA content ranged from $4.5 \pm 0.2$ (CE) to $589 \pm 29$ (SWE) $\mathrm{mg} / 100 \mathrm{~g}$ DW for TN extracts. The obtained concentrations were in agreement with the reported levels for similar extraction techniques (Farhadi et al., 2016; Ju et al., 2016). From the present results, the GA content recovered by SWE should be highlighted since it corresponds to 47 and $75 \%$ of the total amount of phenolic acids quantified in TR and TN extracts, respectively (Table 2). Catechin was another flavanol compound found in significant amount in vine shoot, especially in SWE extracts ( $542 \pm 27$ to $592 \pm 30 \mathrm{mg} / 100 \mathrm{~g}$ DW for TN and TR extracts, respectively). The previous results demonstrated the potential of using SWE for the recovery of these phenolic compounds from vine shoots. In a previous investigation (Aliakbarian et al., 2012), the extraction of phenolic compounds from grape pomace was also enhanced by the use of SWE. These authors reported that TPC, TFC and antiradical activity of vine shoot extracts were 19,12 and 3-fold higher compared to those reached using water in CE. This increase in the reported yield of phenolic compounds recovered by SWE in comparison to the other extraction techniques applied, namely CE and MAE, may be justified by an increase in the aqueous solubility of GA and catechin with the temperature increase from 25 to $150{ }^{\circ} \mathrm{C}$ (Srinivas et al., 2010).

Other phenolic acids, such as protocatechuic, vanillic, syringic, caffeic, ferulic, coumaric and sinapic, were also identified and quantified in vine shoots from other varieties (Delgado-Torre et al., 2012; Gullón et al., 2017; Luque-Rodríguez et al., 2006; Rajha et al., 2015b; SánchezGómez et al., 2014). The detected levels of phenolic compounds reported in the literature were in the same range as the quantified in the Portuguese vine shoot extracts. One exception is the sinapic acid content, which concentration ranged from 5.6 to $228.3 \mathrm{mg} / 100 \mathrm{~g} \mathrm{DW}$ (Delgado-Torre et al., 2012), i.e. 10 times higher than the values obtained in the present study. These results demonstrated that, despite of the vine shoot variety studied, the phenolic composition was very similar. In fact, the results described by Çetin et al. (2011) are also in agreement with this finding, as they demonstrated the importance of vine shoots genotype only in the concentration of phenolic compounds found.

Other phenolic compound, typically found in grapes and their products, is trans-resveratrol, a phytoalexin that belongs to the stilbenes group (Sánchez-Gómez et al., 2014; Silva and Queiroz, 2016). Due to its capacity to inhibit or delay a wide variety of diseases, there are some papers describing the use of vine shoots as a source of transresveratrol for medicinal and anti-phytopathogenic applications (Rayne et al., 2008; Vergara et al., 2012). Some authors have reported high levels of trans-resveratrol in different vine-shoot from vineyards in the Region of Southern Chile $(38.3 \pm 1.2$ and $653 \pm 49 \mathrm{mg} / 100 \mathrm{~g}$ DW) (Vergara et al., 2012), whereas in Turkish or Canadian cultivars the attained concentrations ranged from $0.95 \pm 0.08$ to $3.94 \pm 0.21$ $\mu \mathrm{g} / 100 \mathrm{~g}$ DW and $1.95 \pm 0.07$ to $3.40 \pm 0.18 \mathrm{mg} / \mathrm{g} D W$, respectively (Çetin et al., 2011; Karacabey et al., 2012). In the present work, TR extracts prepared by CE and MAE techniques exhibited at least 2-fold higher levels of trans-resveratrol than TN variety (Table 2). According to some authors (Çetin et al., 2011; Rayne et al., 2008; Vergara et al., 2012), the higher content of trans-resveratrol could be attributed to an increased synthesis of this compound due to a possible response of TR variety to disease or injury stresses. In the case of SWE extracts, the amount extracted was 7-times lower than the achieved through the other tested techniques $(9.41 \pm 0.47$ vs $69.2 \pm 3.5$ and $73.9 \pm$ $3.7 \mathrm{mg} / 100 \mathrm{~g}$ DW for SWE, CE and MAE techniques for TN variety), which could be related to the stability of trans-resveratrol under SWE 
Table 2

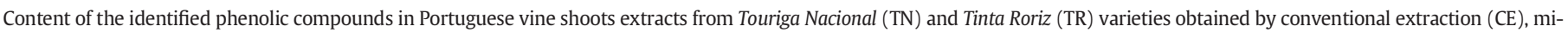

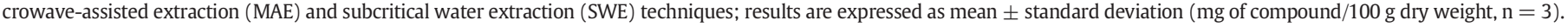

\begin{tabular}{|c|c|c|c|c|c|c|}
\hline \multirow[t]{2}{*}{ Compound } & \multicolumn{3}{|c|}{ Touriga Nacional (TN) } & \multicolumn{3}{|c|}{ Tinta Roriz (TR) } \\
\hline & $\mathrm{CE}$ & MAE & SWE & $\mathrm{CE}$ & MAE & SWE \\
\hline \multicolumn{7}{|l|}{ Phenolic acids } \\
\hline Gallic acid & $4.5 \pm 0.2$ & $21.4 \pm 1.1$ & $589 \pm 29$ & $4.63 \pm 0.23$ & $109 \pm 5$ & $175 \pm 9$ \\
\hline Protocatechuic acid & $7.0 \pm 0.4$ & $11.3 \pm 0.6$ & $40.9 \pm 2.0$ & $6.17 \pm 0.31$ & $10.5 \pm 0.5$ & $35.8 \pm 1.8$ \\
\hline 4-Hydroxyphenilacetic acid & $6.0 \pm 0.3$ & $2.32 \pm 0.11$ & $26.6 \pm 1.3$ & $12.4 \pm 0.6$ & $4.85 \pm 0.24$ & $28.6 \pm 1.4$ \\
\hline 4-Hydroxybenzoic acid & $3.1 \pm 0.2$ & ND & $3.14 \pm 0.16$ & $\mathrm{ND}$ & ND & $2.62 \pm 0.13$ \\
\hline 4-Hydroxybenzaldehyde & $7.1 \pm 0.4$ & $30.9 \pm 1.5$ & $12.4 \pm 0.6$ & $8.27 \pm 0.41$ & $32.3 \pm 1.6$ & $9.89 \pm 0.49$ \\
\hline Chlorogenic acid & $11.4 \pm 0.6$ & $37.2 \pm 1.9$ & $8.40 \pm 0.42$ & $5.73 \pm 0.28$ & $42.3 \pm 2.1$ & $9.21 \pm 0.46$ \\
\hline Vanillic acid & $4.8 \pm 0.2$ & $7.80 \pm 0.39$ & $9.44 \pm 0.47$ & $3.72 \pm 0.19$ & $8.58 \pm 0.43$ & $10.6 \pm 0.5$ \\
\hline Caffeic acid & $4.8 \pm 0.3$ & $24.8 \pm 1.2$ & $24.8 \pm 1.2$ & $4.61 \pm 0.23$ & $24.8 \pm 1.2$ & $30.4 \pm 1.5$ \\
\hline Syringic acid & $2.3 \pm 0.1$ & $7.13 \pm 0.36$ & $10.3 \pm 0.5$ & ND & $7.13 \pm 0.36$ & ND \\
\hline p-Coumaric acid & $7.7 \pm 0.4$ & $18.0 \pm 0.9$ & $4.93 \pm 0.24$ & $6.31 \pm 0.32$ & $21.3 \pm 1.1$ & $5.11 \pm 0.26$ \\
\hline Ferulic acid & $2.8 \pm 0.1$ & $16.1 \pm 0.8$ & $19.9 \pm 0.9$ & $2.97 \pm 0.14$ & $16.9 \pm 0.8$ & $20.7 \pm 1.0$ \\
\hline Sinapic acid & $3.7 \pm 0.2$ & $20.7 \pm 1.0$ & $26.1 \pm 1.3$ & $3.68 \pm 0.18$ & $23.3 \pm 1.2$ & $26.6 \pm 1.3$ \\
\hline Cinnamic acid & $5.2 \pm 0.3$ & $22.8 \pm 1.1$ & $5.07 \pm 0.25$ & $6.27 \pm 0.31$ & $23.4 \pm 1.2$ & $5.61 \pm 0.28$ \\
\hline Ellagic acid & $6.9 \pm 0.3$ & $45.0 \pm 2.3$ & $8.62 \pm 0.43$ & $6.80 \pm 0.34$ & $39.9 \pm 2.0$ & $8.08 \pm 0.40$ \\
\hline$\sum$ Phenolic acids & $77.3 \pm 3.9$ & $265 \pm 13$ & $790 \pm 40$ & $71.5 \pm 3.6$ & $365 \pm 18$ & $368 \pm 18$ \\
\hline \multicolumn{7}{|l|}{ Flavanols } \\
\hline Catechin & $39.4 \pm 2.0$ & $31.6 \pm 1.6$ & $542 \pm 27$ & $99.6 \pm 5.0$ & $109 \pm 5$ & $592 \pm 30$ \\
\hline Epicatechin & $7.22 \pm 0.36$ & $13.6 \pm 0.7$ & $2.73 \pm 0.14$ & $15.9 \pm 0.8$ & $24.2 \pm 1.2$ & $2.41 \pm 0.12$ \\
\hline$\sum$ Flavanols & $46.6 \pm 2.3$ & $45.2 \pm 2.3$ & $545 \pm 27$ & $115 \pm 6$ & $133 \pm 7$ & $594 \pm 29$ \\
\hline \multicolumn{7}{|l|}{ Flavanones } \\
\hline Naringin & $5.82 \pm 0.29$ & $9.95 \pm 0.50$ & $11.3 \pm 0.6$ & $5.39 \pm 0.27$ & $11.3 \pm 0.6$ & $14.1 \pm 0.7$ \\
\hline Naringenin & $2.12 \pm 0.11$ & $50.8 \pm 2.5$ & $2.10 \pm 0.11$ & $2.31 \pm 0.11$ & $29.4 \pm 1.5$ & $2.04 \pm 0.10$ \\
\hline Pinocembrin & $6.96 \pm 0.35$ & $41.2 \pm 2.1$ & $8.18 \pm 0.41$ & $6.92 \pm 0.34$ & $40.9 \pm 2.0$ & $8.18 \pm 0.41$ \\
\hline$\sum$ Flavanones & $14.9 \pm 0.7$ & $102 \pm 5$ & $21.6 \pm 1.1$ & $14.6 \pm 0.7$ & $81.7 \pm 4.1$ & $24.3 \pm 1.2$ \\
\hline \multicolumn{7}{|l|}{ Flavonols } \\
\hline Rutin & $20.5 \pm 1.0$ & $23.4 \pm 1.2$ & $3.71 \pm 0.18$ & $38.9 \pm 1.9$ & $42.5 \pm 2.13$ & $3.01 \pm 0.15$ \\
\hline Quercetin-3-O-glucopyranoside & $13.0 \pm 0.7$ & $39.9 \pm 2.0$ & $8.12 \pm 0.41$ & $7.10 \pm 0.36$ & $39.9 \pm 1.9$ & $19.9 \pm 0.9$ \\
\hline Myricetin & $49.9 \pm 2.5$ & $280 \pm 14$ & $55.7 \pm 2.8$ & $50.9 \pm 2.5$ & $281 \pm 14$ & $55.6 \pm 2.8$ \\
\hline Kaempferol-3-O-glucoside & $12.5 \pm 0.6$ & $42.5 \pm 2.1$ & $8.45 \pm 0.42$ & $12.1 \pm 0.6$ & $42.9 \pm 2.1$ & $8.29 \pm 0.41$ \\
\hline Kaempferol-3-O-rutinoside & $7.78 \pm 0.39$ & $125 \pm 6$ & $8.86 \pm 0.44$ & $8.32 \pm 0.42$ & $70.9 \pm 3.5$ & $10.1 \pm 0.5$ \\
\hline Quercetin & $14.1 \pm 0.7$ & $78.6 \pm 3.9$ & $21.3 \pm 1.1$ & $17.9 \pm 0.9$ & $82.1 \pm 4.1$ & $15.9 \pm 0.8$ \\
\hline Tiliroside & $6.09 \pm 0.30$ & $32.3 \pm 1.6$ & $6.53 \pm 0.33$ & $5.52 \pm 0.27$ & $31.5 \pm 1.6$ & $6.50 \pm 0.32$ \\
\hline Kaempferol & $18.9 \pm 0.9$ & $89.5 \pm 4.5$ & $17.7 \pm 0.88$ & $16.3 \pm 0.81$ & $88.4 \pm 4.4$ & $17.5 \pm 0.9$ \\
\hline$\sum$ Flavonols & $143 \pm 7$ & $712 \pm 35$ & $130 \pm 6$ & $157 \pm 8$ & $680 \pm 34$ & $137 \pm 7$ \\
\hline \multicolumn{7}{|l|}{ Stilbenes } \\
\hline Resveratrol & $69.2 \pm 3.5$ & $73.9 \pm 3.7$ & $9.41 \pm 0.47$ & $133 \pm 6$ & $136 \pm 7$ & $9.39 \pm 0.47$ \\
\hline$\sum$ Stilbenes & $69.2 \pm 3.5$ & $73.9 \pm 3.7$ & $9.41 \pm 0.47$ & $133 \pm 6$ & $136 \pm 7$ & $9.39 \pm 0.47$ \\
\hline \multicolumn{7}{|l|}{ Others } \\
\hline Phloridzin & $6.70 \pm 0.33$ & $15.2 \pm 0.76$ & $3.60 \pm 0.18$ & $7.03 \pm 0.35$ & $14.8 \pm 0.7$ & $7.10 \pm 0.35$ \\
\hline Phloretin & $2.45 \pm 0.12$ & $13.9 \pm 0.70$ & $2.50 \pm 0.12$ & $2.11 \pm 0.10$ & $10.6 \pm 0.5$ & $2.13 \pm 0.11$ \\
\hline EOthers & $9.15 \pm 0.46$ & $29.1 \pm 1.4$ & $6.09 \pm 0.30$ & $9.14 \pm 0.46$ & $25.4 \pm 1.3$ & $9.24 \pm 0.46$ \\
\hline$\sum$ All phenolic compounds & 360 & 1228 & 1502 & 501 & 1421 & 1142 \\
\hline
\end{tabular}

ND: not detected.

conditions used. In a previous investigation (Rayne et al., 2008), a decrease in trans-resveratrol yield of 7-fold between the solvent systems 70:30 ethanol:water (v/v) (345 $\pm 4 \mathrm{mg} / 100 \mathrm{~g} \mathrm{DW})$ and 30:70 ethanol:water (v/v) ( $47 \pm 9 \mathrm{mg} / 100 \mathrm{~g}$ DW) was stated, which could explain the low amount recovered by SWE due to the extraction solvent used. Furthermore, the higher temperature $\left(150^{\circ} \mathrm{C}\right)$ used in SWE can also influence the trans-resveratrol extraction, which can thermally decompose at this temperature.

The identification of rutin, quercetin and kaempferol, phenolic compounds belonging to the flavonoid family, in vine shoots has been previously reported by other authors (Farhadi et al., 2016; Rajha et al., 2014c). For the Portuguese extracts among the extraction techniques tested, the yield of rutin was the highest for MAE $(42.5 \pm 2.1$ and 23.4 $\pm 1.2 \mathrm{mg} / 100 \mathrm{~g}$ DW for TR and TN, respectively), followed by CE (39.0 \pm 1.9 and $20.5 \pm 1.0 \mathrm{mg} / 100 \mathrm{~g} \mathrm{DW}$, for TR and TN, respectively) and then SWE $(3.01 \pm 0.15$ and $3.71 \pm 0.19 \mathrm{mg} / 100 \mathrm{~g}$ DW, for TR and TN, respectively). For quercetin and kaempferol, MAE also enabled to obtain the highest content, which was very similar for CE and SWE techniques (Table 2). These results confirmed the influence of the extraction technique in the yield of phenolic compounds recovered, demonstrating that MAE seems to be more suitable for the recovery of compounds belonging to the flavonoid family. Other flavonoids, namely quercetin-30 -glucopyranoside, myricetin, kaempferol-3-O-glucoside, kaempferol3-O-rutinoside, tiliroside, naringenin and pinocembrin, were identified in vine shoot extracts for the first time. Again, the highest yield was reported for the MAE extracts, confirming the applicability of this extraction technique for the recovery of flavonoid compounds.

\subsection{Antioxidant activity}

\subsubsection{FRAP and DPPH-RSA assays}

In the present study, FRAP and DPPH-RSA assays were used to assess the antioxidant activity of Portuguese vine shoot extracts obtained after the application of the three tested extraction techniques (Table 3). In general, the antioxidant activity of TR was significantly higher $(p<$ 0.05 ) than that of TN, which is in accordance with previous results obtained for TPC and TFC assays. Among the extraction techniques applied, TR extracts obtained by SWE exhibited the highest reducing power by FRAP assay ( $24.3 \pm 0.9 \mathrm{mg}$ AAE/g DW), as well as the highest radicalscavenging activity by DPPH method (35.3 $\pm 2.4 \mathrm{mg}$ TE/g DW). On 
the other hand, TN extracts prepared by the CE presented at least 3times lower values than the TR $(7.25 \pm 0.31 \mathrm{mg} \mathrm{AAE} / \mathrm{g}$ DW and 8.31 $\pm 0.32 \mathrm{mg}$ TE/g DW for FRAP and DPPH-RSA assays, respectively). Several authors (Alexandru et al., 2014; Delgado-Torre et al., 2012; Farhadi et al., 2016; Ju et al., 2016; Karacabey and Mazza, 2010; Rajha et al., 2014a; Rajha et al., 2015b) have been investigating the antioxidant activity of other vine shoot varieties employing different assays and one of the most used was the DPPH method. Despite of that, a direct comparison with ours results is not possible as the majority of those works reported the values in terms of inhibition percentage $\left(\mathrm{IC}_{50}\right)$. Moreover, a huge variability in the determined antioxidant activity within the same vine shoot variety, but applying different analytical methods, extraction conditions and/or techniques, was found in most of the published studies (Alexandru et al., 2014; Farhadi et al., 2016; Ju et al., 2016; Rajha et al., 2015b).

The results from FRAP and DPPH-RSA assays showed the same tendency as that previously described for TPC and TFC methods, with an increase in the values of the extracts prepared by the environmentally friendly extraction techniques MAE and SWE. A previous study (Karacabey and Mazza, 2010) has indicated that an increase in temperature led to an increase of antioxidant activity, which agreed with MAE and SWE results since assays were conducted at 100 and $150{ }^{\circ} \mathrm{C}$, respectively, versus to the $\mathrm{CE}$, which was performed at $55^{\circ} \mathrm{C}$. The same authors also demonstrated that the solvent polarity was one of the most significant extraction factor affecting not only the quantity of total phenolics, but also the composition and the antioxidant activity of vine shoots extracts (Karacabey and Mazza, 2010). Therefore, the main differences in the phenolic profile of the obtained extracts may be related, not only with the extraction technique employed, but also with the use of different solvent compositions which may result in the change of the phenolic profile, and consequently in the antioxidant activity of vine shoot extracts (Table 3). According to the reached results, the amount of the investigated phenolic compounds (especially in GA and catechin, Table 2) seems to have a positive effect on the antioxidant activity of the Portuguese vine shoot extracts.

Another factor that may justify the higher antioxidant activity of the SWE extracts could be the formation of new compounds due to the use of higher extraction temperatures (Delgado de la Torre et al., 2012; Plaza et al., 2010). Plaza et al. (2010) demonstrated that some components originally present in the samples can be released and interact through Maillard and caramelization reactions forming new compounds during SWE, which affect the antioxidant activity of subcritical water extracts. In a recent study (Delgado de la Torre et al., 2012), taking in consideration the employed extraction temperature, as well as the amount of cellulose and hemicellulose in vine shoots, it was suggested that furanic compounds could be formed under SWE. In fact, according to Senyuva and Gokmen (2007), the formation of furans could be significantly increased at temperatures higher than $120^{\circ} \mathrm{C}$ due to the degradation of sugars released from vine shoots material, which could explain the higher antioxidant activity found in the present study for SWE vine shoot extracts. However, the furanic compounds have been a target of disagreement (Delgado de la Torre et al., 2012). On the one hand, it is well-known the contribution of furfural and hydroxymethylfurfural to flavoring in processed food by heating. On the other hand, several organizations, such as the Food and Drug Administration in United States (U.S. FDA) and the European Food Safety Authority (EFSA), have reported that these compounds could be harmful, as they demonstrated carcinogenic activity in rats and mice, probably due to the combination of a genotoxic mechanism and hepatotoxicity (Delgado de la Torre et al., 2012). Therefore, for a potential application of the produced vine shoot extracts in food and/or pharmaceutical industries, it is important to evaluate the furan contents to ensure products safety.

\subsubsection{Protective effect on AAPH-induced hemolysis}

The hemolytic activity of Portuguese vine shoot extracts and their capacity to protect the erythrocytes against hemolysis induced by the oxidizing agent AAPH were assessed (Table 3). The vine shoot extracts were incubated with erythrocytes in the absence of AAPH and no hemolysis was observed during the experimental period, for all concentrations tested. All extracts significantly protected erythrocytes against AAPH-induced hemolysis, with $\mathrm{IC}_{50}$ values after $3 \mathrm{~h}$ of incubation ranging from $9.59 \pm 1.04$ (MAE for TR) to $21.3 \pm 0.3 \mu \mathrm{g} / \mathrm{mL}$ (SWE for TN) (Table 3). The anti-hemolytic action observed for ascorbic acid, used as a positive control due to its consensual antioxidant properties, was significant lower $(p<0.05)$ than that obtained for the Portuguese vine shoots, with an $\mathrm{IC}_{50}$ value of $50 \mu \mathrm{g} / \mathrm{mL}$. Moreover, the antioxidant effect observed in this study was similar to that reported by Pervin et al. (2014) for grape skin, suggesting that the analyzed vine shoot samples could be used in the prevention of oxidative stress, maintaining the integrity of the cell wall. These results could be explained by the synergistic interactions of the compounds present in the vine shoots, particularly the phenolic compounds, which act as hydrogen donors, singlet oxygen reducers and superoxide radicals, antioxidant enzyme activators and as metal chelators protecting against the oxidation (Pervin et al., 2014). The generation of free radicals in the absence of efficient neutralization systems has been claimed to be a leading pathological mechanism in neuronal disorders such as Alzheimer and Parkinson, cancer, diabetes and atherosclerosis (Farias et al., 2014). Having this into consideration, following the confirmation that Portuguese vine shoot possess antioxidant activity and protect erythrocytes against oxidative damage, further studies were conducted in order to investigate the inhibition of acetylcholinesterase and $\alpha$-amylase activity.

\subsection{Acetylcholinesterase inhibition assay}

Alzheimer's disease represents 60 to $80 \%$ of dementia cases worldwide, being the sixth leading cause of death in the United States (Farias et al., 2014). The inhibition of acetylcholinesterase enzyme, which plays a key role in the degradation of acetylcholine, appears as a sound strategy for the treatment of Alzheimer's disease (Farias et al., 2014; Pervin et al., 2014). However, despite the great efforts developed by researchers and the pharmaceutical industry, the therapeutically

\section{Table 3}

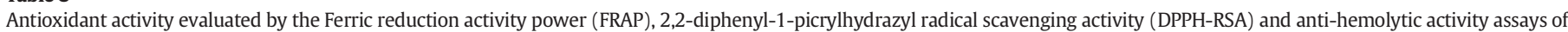

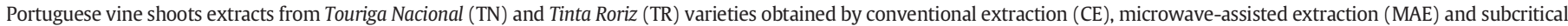

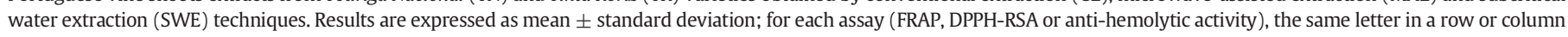
indicates that the given means are not statistically significant $(p>0.05)$.

\begin{tabular}{|c|c|c|c|c|c|c|}
\hline \multirow[t]{2}{*}{ Extraction technique } & \multicolumn{2}{|c|}{$\begin{array}{l}\text { FRAP } \\
(\mathrm{mg} \mathrm{AAE} / \mathrm{g} \mathrm{DW})^{1}\end{array}$} & \multicolumn{2}{|c|}{$\begin{array}{l}\text { DPPH-RSA } \\
(\mathrm{mg} \mathrm{TE} / \mathrm{g} \mathrm{DW})^{2}\end{array}$} & \multicolumn{2}{|c|}{$\begin{array}{l}\text { Anti-hemolytic activity } \\
\mathrm{IC}_{50}(\mu \mathrm{g} / \mathrm{mL})\end{array}$} \\
\hline & $\mathrm{TN}$ & TR & TN & TR & $\mathrm{TN}$ & TR \\
\hline $\mathrm{CE}$ & $7.25 \pm 0.31 \mathrm{a}$ & $10.5 \pm 0.9 d$ & $8.31 \pm 0.32 a$ & $15.4 \pm 0.2 c$ & $16.1 \pm 0.6 a$ & $15.3 \pm 0.9 a$ \\
\hline MAE & $15.2 \pm 0.9 b$ & $20.1 \pm 1.1 \mathrm{e}$ & $22.4 \pm 1.9 b$ & $31.3 \pm 2.4 d$ & $12.3 \pm 0.3 b$ & $9.59 \pm 1.04 d$ \\
\hline SWE & $20.2 \pm 1.7 c$ & $24.3 \pm 0.9 f$ & $24.8 \pm 1.9 b$ & $35.3 \pm 2.4 d$ & $21.3 \pm 0.3 c$ & $17.9 \pm 0.7 e$ \\
\hline
\end{tabular}

\footnotetext{
1 FRAP: ferric reduction activity power, results are expressed as mg ascorbic acid equivalents/g dry weight.

2 DPPH-RSA: 2,2-diphenyl-1-picrylhydrazyl radical scavenging activity, results are expressed as mg trolox equivalents/g dry weight.
} 
armamentarium that effectively reduces the progression of this disease is still scarce. Recently, special attention has been given to nutraceuticals and bioactive compounds that may be obtained directly from diet or supplementation. These compounds may be able to modify the pathophysiological processes responsible for neurodegeneration, among which the deleterious activity of acetylcholinesterase (Farias et al., 2014). In the present study, all the Portuguese vine shoot extracts inhibited the acetylcholinesterase enzyme (Fig. 2). Portuguese vine shoot extracts obtained by MAE technique, with $\mathrm{IC}_{50}$ values of 17.18 \pm 2.59 and $24.33 \pm 0.76 \mu \mathrm{g} / \mathrm{mL}$ for TR and TN varieties, respectively, presented the highest acetylcholinesterase inhibition activity. On the other hand, TN and TR extracts prepared by the SWE presented $\mathrm{IC}_{50}$ values at least 5-fold higher than the reported for MAE extracts, resulting in a lower inhibitory effect of the enzyme under study. The inhibition induced by Eserine ( $\mathrm{IC}_{50}: 0.005 \pm 0.002 \mu \mathrm{g} / \mathrm{mL}$ ), used as a control standard, differed statistically $(p<0.05)$ from that obtained when using the extracts. The comparison of our results with those available in the literature (Pervin et al., 2014), namely with $\mathrm{IC}_{50}$ values of grape skins from V. vinifera L. cv. Aglianico $(363.6 \mu \mathrm{g} / \mathrm{mL})$ and the phenolic standards gallic and ellagic acids ( 1.1 and $13.79 \mu \mathrm{g} / \mathrm{mL}$, respectively) which possess recognized benefits in the Alzheimer's disease treatment, suggest that vine shoot extracts obtained by MAE may be an important natural source of components to be included in the treatment of this health condition.

\section{5. $\alpha$-Amylase inhibition assay}

Diabetes mellitus is a complex and multifactorial metabolic disorder whose prevalence is increasing worldwide, reaching $15 \%$ in some countries. Diabetes-related complications impose a relevant burden on all health-care systems and have been much related to the oxidative stress (Ayeleso et al., 2016). The financial costs of treatments with conventional drugs, such as acarbose and mignitol, and the side effects inherent to the treatment of this disease have aroused the interest of both scientific community and pharmaceutical industry for the development of therapeutic alternatives, particularly those enrolling naturally available compounds (Ayeleso et al., 2016; Lavelli et al., 2016). Nowadays, the therapeutic approach to treat Diabetes mellitus emphasizes the reduction of postprandial hyperglycemia, what may be achieved by inhibiting the enzymes involved in the digestion of carbohydrates in humans, among which $\alpha$-amylase (Thilagam et al., 2013).

In this context, $\alpha$-amylase inhibition activity from vine shoot extracts was evaluated and the obtained results are also presented in Fig. 2. It was observed that TR and TN extracts obtained by MAE were those that inhibited the $\alpha$-amylase enzyme to a greater extent with $\mathrm{IC}_{50}$ values of $60.37 \pm 5.55$ and $73.28 \pm 6.77 \mu \mathrm{g} / \mathrm{mL}$, respectively. Indeed, the mentioned extracts also showed $\alpha$-amylase inhibitory activity identical $(p>0.05)$ to that of the reference compound acarbose $\left(\mathrm{IC}_{50}\right.$ :
$67.52 \pm 2.42 \mu \mathrm{g} / \mathrm{mL}$ ). In an opposite way, the $\alpha$-amylase inhibition induced by the extracts prepared by SWE technique was at least 4.6-fold lower than the samples referred above. Literature studies on the $\alpha$ amylase inhibitory effect of vine shoots are missing. Although, recently it was reported that other by-products from the winemaking process, namely grape seed and skins, may possess a significant inhibitory activity of $\alpha$-amylase (Lavelli et al., 2016). Therefore, vine shoots could present these inhibition properties.

Plant polyphenols and flavonoids, already identified and quantified in these samples, are some of the naturally occurring antidiabetic agents which are known to show an inhibitory effect on carbohydrate hydrolyzing enzyme inhibition due to their capability to bind with proteins (Ayeleso et al., 2016). In the present study, TPC and TFC values obtained for the extracts prepared by the MAE and SWE techniques were not significantly different $(p>0.05)$. However, their $\alpha$-amylase inhibition properties were statistically different $(p<0.05)$. These findings suggest that $\alpha$-amylase, as well as acetylcholinesterase inhibitory activities are not directly linked to the content of phenolic or flavonoid compounds, but perhaps to the presence of specific polyphenols. The same behavior was also observed by Sousa and Correia (2012), who confirm that the quality and the synergy of phytochemicals may be more relevant to enzyme inhibition than the total amount of phenolic or flavonoid compounds itself. Considering the obtained previous results for vine shoot extracts, this research enables us to conclude that this vineyard waste demonstrates further potential for being used in the treatment of Alzheimer and diabetes's diseases.

\subsection{Antimicrobial activity}

Recently, the emergence of multiresistant drug strains, both in inhospital environment and in the community, has reduced the efficacy of several antibiotics (Gullón et al., 2017). Natural products, due to their complexity and varying characteristics, may constitute potential sources of compounds with antimicrobial activity (Gullón et al., 2017; Teixeira et al., 2014). Recently, several studies have reported that grape by-products, such as grape pomace and seeds, possess antimicrobial activity (Gullón et al., 2017, Teixeira et al., 2014). In fact, Gullón et al. (2017) evaluated the antimicrobial activity of ethyl acetate extracts from the vine shoots liquors against several microorganisms associated with spoilage of food products, reporting MIC and MLC values ranging from 5 to $20 \mathrm{mg} / \mathrm{mL}$. Despite from the previous mentioned study (Gullón et al., 2017), information from the antimicrobial activity of vine shoot extracts is still scarce.

Table 4 depicts the MIC and MLC values obtained for the bacteria and yeasts included in this study, both isolated from hospital and reference strains. As it can be seen, all the vine shoot extracts demonstrated antimicrobial activity against both reference microorganisms and strains resistant to antimicrobial drugs. Moreover, the studied activity was
A

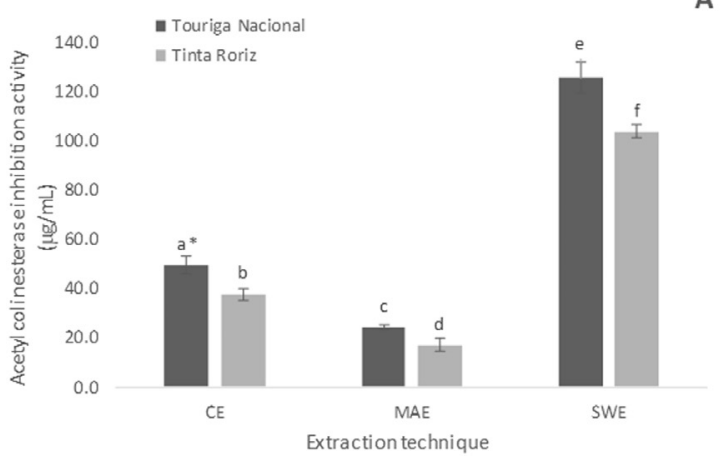

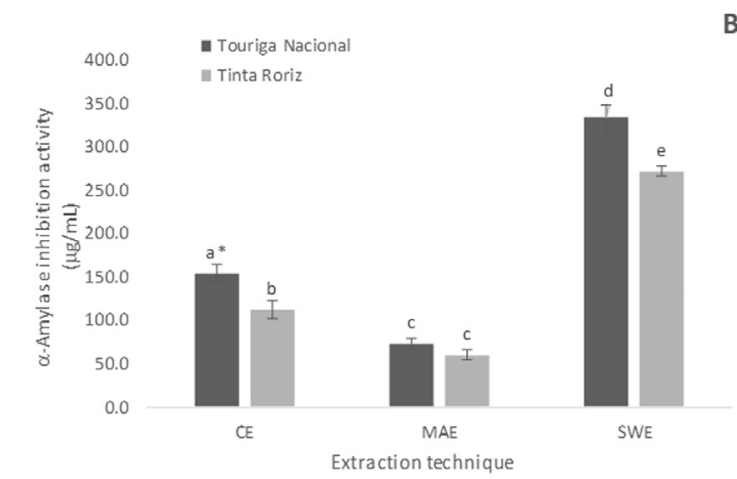

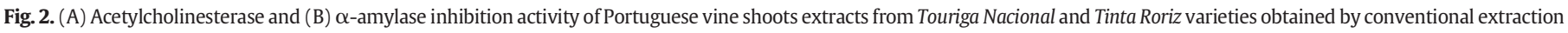

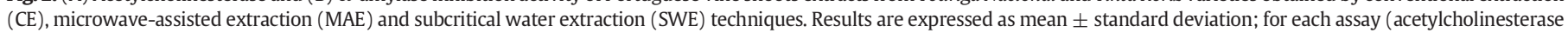
and $\alpha$-amylase inhibition activity), the same letter in a plot indicates that the given means are not statistically significant $(p>0.05)$. 


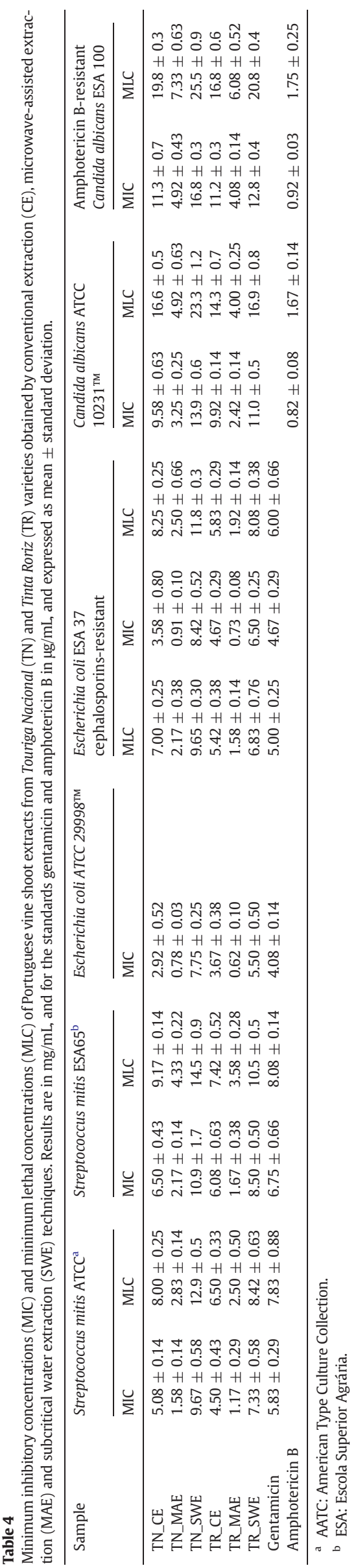

influenced by the vine shoot variety, as well as by the extraction technique applied, with TR variety and MAE technique presenting the highest antimicrobial activity. The bacterial activity of $S$. mitis, considered as one of the main microorganisms involved in periodontal diseases, was particularly inhibited when the MAE extract from TR variety was used with MIC values of $1.17 \pm 0.29$ and $1.67 \pm 0.38 \mathrm{mg} / \mathrm{mL}$ for S. mitis ATCC and S. mitis ESA65, respectively. Regarding the MLC, the lowest values were observed for the $S$. mitis ATCC strain, with their content ranging from $2.50 \pm 0.50$ to $12.9 \pm 0.5 \mathrm{mg} / \mathrm{mL}$ for TR extract obtained by MAE and TN extract prepared by SWE, respectively. Even though the bacterial strains accessed are different, our values are similar to those reported by Gullón et al. (2017) who reported MIC and MLC of 5 and $10 \mathrm{mg} / \mathrm{mL}$ for S. aureus and L. innocua strains, respectively. Regarding the Gram-negative bacteria studied, E. coli ESA 37 Cephalosporinsresistant strain was the one that presented higher resistance in the presence of TN extract obtained by SWE technique, with MIC of $8.42 \pm$ $0.52 \mathrm{mg} / \mathrm{mL}$ and MLC of $11.8 \pm 0.3 \mathrm{mg} / \mathrm{mL}$. On the other hand, TR extract obtained by MAE was, again, the most effective sample in inhibiting the growth of Gram-negative bacteria presenting MIC $(0.62 \pm 0.10 \mathrm{mg} / \mathrm{mL})$ and MLC $(1.58 \pm 0.14 \mathrm{mg} / \mathrm{mL})$ lower than that reported for Grampositive bacteria's. In contrast, Gullón et al. (2017) reported that their vine shoot ethyl acetate extracts were less effective against $E$. coli reporting MIC and MLC values of 15 and $20 \mathrm{mg} / \mathrm{mL}$, respectively, which were significantly higher than the obtained in the present study even for the Portuguese vine shoot extract with the lowest antimicrobial activity.

Concerning the antifungal activity, TN and TR extracts were active against both reference and hospital strains. The C. albicans ATCC 10231 yeast was the most sensitive to the negative effects induced by the vine shoot extracts, especially in the presence of the TR extract obtained by MAE technique (MIC $=2.42 \pm 0.14 \mathrm{mg} / \mathrm{mL}$ and $\mathrm{MLC}=4.00 \pm$ $0.25 \mathrm{mg} / \mathrm{mL}$ ). On the other hand, amphotericin B-resistant $C$. albicans ESA 100 of hospital origin showed the highest resistance, with the maximum MIC $(16.8 \pm 0.3 \mathrm{mg} / \mathrm{mL})$ and MLC $(25.5 \pm 0.9 \mathrm{mg} / \mathrm{mL})$ reported for TN extract obtained by SWE technique.

Even though some studies indicated that antibacterial and antifungal activities may be assigned to the total amount of phenolic compounds (Teixeira et al., 2014), no correlation between the antimicrobial activity and TPC or TFC was found in the present work. Indeed, the subcritical extracts, with higher amount of total phenolic and flavonoid compounds, were the less effective against the studied microorganisms. These findings suggest that other factors, like the particular type of the phenolic compounds available in the extracts as well as the complex mixture of several bioactive molecules, may justify this discrepancy. In fact, several authors have reported that the antibacterial activity of different extracts is due to a synergistic effect between various constituents that are present in their composition (Gullón et al., 2017, Teixeira et al., 2014). Furthermore, from the attained results (Table 4 ), it may be highlighted that the inhibitory potential of vine shoot extracts on Gram-negative bacteria was higher than the observed on Gram-positive bacteria and yeast. Usually, the majority of compounds or extracts are more efficient against Gram-positive bacteria than to Gram-negative, due to the composition of the bacterial cell wall (Gullón et al., 2017). However, even though Gram-negative bacteria have a flexible cell wall their chemical structure is also more complex, with highly polar characteristics as well as the presence of efflux pumps that act as resistance mechanisms by ejecting compounds that passed across the outer membrane (Gullón et al., 2017). As far as we know, no previous studies reported a higher efficiency of plant extracts against Gramnegative bacteria in comparison to Gram-positive ones. Therefore, these important findings enable us to conclude regarding the huge potential of Portuguese vine shoots from TR and TN varieties to be used in the development of bioactive agents or supplements to be further employed by food or pharmaceutical industries in the treatment of several diseases. 


\section{Conclusions}

The results obtained in the present study demonstrate that Portuguese vine shoots, especially TR variety, constitute a good source of bioactive compounds, namely polyphenols. MAE shows to be the extraction technique, which enables to obtain higher phenolic content (32.1 $\pm 0.9 \mathrm{mg} \mathrm{GAE} / \mathrm{g} \mathrm{DW})$, whereas the maximum flavonoid content was reported for SWE (18.7 $\pm 1.2 \mathrm{mg} E \mathrm{E} / \mathrm{g} \mathrm{DW})$, being both values for TR variety. Concerning the antioxidant activity, assessed by FRAP and DPPH-RSA assays, the highest results were reported for SWE, followed by MAE and CE techniques. Regarding the protective effect on AAPHinduced hemolysis, MAE extracts were the most effective ( $\mathrm{IC}_{50}: 9.59$ $\pm 1.04 \mu \mathrm{g} / \mathrm{mL}$ for TR variety). Additionally, for the first time, vine shoot extracts showed inhibitory activities against $\alpha$-amylase and acetylcholinesterase enzymes, indicating their potential to be used in the treatment of Alzheimer and diabetes's diseases. The characterization of phenolic profile by HPLC analysis indicate that gallic acid, and the flavonoids catechin, myricetin and kaempferol-3-O-rutinoside were the major contributors to the demonstrated antioxidant and biological activities of the vine shoot extracts. It can also be concluded that the vine shoot extracts, that showed high antioxidant, namely antihemolytic activity, as well as high antimicrobial activity, in particular MAE extracts, could serve as easily accessible source of natural antioxidants for the food or pharmaceutical industries.

\section{Acknowledgments}

Manuela M. Moreira (SFRH/BPD/97049/2013) and M. F. Barroso (SFRH/BPD/78845/2011) are grateful for the postdoctoral fellowships financed by POPH-QREN - Tipologia 4.1 - Formação Avançada, subsidized by Fundo Social Europeu and Ministério da Ciência, Tecnologia e Ensino Superior. The authors are also grateful for the financial support from FCT/MEC through national funds and co-financed by FEDER, under the Partnership Agreement PT2020 through the project UID/QUI/50006/ 2013 - POCI/01/0145/FEDER/007265; the project 6818 - Transnational Cooperation, Agreement between Portugal (FCT) and Serbia (MSTD) is also acknowledged. This work was also supported by the strategic programme UID/BIA/04050/2013 (POCI-01-0145-FEDER-007569) funded by national funds through the FCT I.P. and by the ERDF through the COMPETE2020 - Programa Operacional Competitividade e Internacionalização (POCI). The supply of the vine shoots is acknowledged to Sogrape Vinhos, S.A.

\section{References}

Alexandru, L., Binello, A., Mantegna, S., Boffa, L., Chemat, F., Cravotto, G., 2014. Efficient green extraction of polyphenols from post-harvested agro-industry vegetal sources in Piedmont. C. R. Chim. 17:212-217. https://doi.org/10.1016/j.crci.2013.09.012.

Aliakbarian, B., Fathi, A., Perego, P., Dehghani, F., 2012. Extraction of antioxidants from winery wastes using subcritical water. J. Supercrit. Fluids 65:18-24. https://doi.org/ 10.1016/j.supflu.2012.02.022

Ayeleso, A., Brooks, N., Oguntibeju, O., Mukwevho, E., 2016. Natural antioxidant vitamins: a review of their beneficial roles in management of diabetes mellitus and its complications. Trop. J. Pharm. Res. 15, 1341-1348.

Campos, J.F., de Castro, D.T.H., Damião, M.J., Vieira Torquato, H.F., Paredes-Gamero, E.J., Carollo, C.A., Estevinho, L.M., de Picoli Souza, K., Santos, E.L.D., 2016. The chemical profile of Senna velutina leaves and their antioxidant and cytotoxic effects. Oxidative Med. Cell. Longev. 2016:12. https://doi.org/10.1155/2016/8405957.

Çetin, E.S., Altinöz, D., Tarçan, E., Göktürk Baydar, N., 2011. Chemical composition of grape canes. Ind. Crop. Prod. 34:994-998. https://doi.org/10.1016/j.indcrop.2011.03.004

Delgado de la Torre, M.P., Priego-Capote, F., Luque de Castro, M.D., 2012. Evaluation of the composition of vine shoots and oak chips for oenological purposes by superheated liquid extraction and high-resolution liquid chromatography-time-of-flight/mass spectrometry analysis. J. Agric. Food Chem. 60:3409-3417. https://doi.org/10.1021/ jf205337a.

Delgado-Torre, M.P., Ferreiro-Vera, C., Priego-Capote, F., Pérez-Juan, P.M., Luque de Castro M.A.D., 2012. Comparison of accelerated methods for the extraction of phenolic compounds from different vine-shoot cultivars. J. Agric. Food Chem. 60:3051-3060. https://doi.org/10.1021/jf205078k.

Ellman, G.L., Courtney, K.D., Andres, V., Featherstone, R.M., 1961. A new and rapid colorimetric determination of acetylcholinesterase activity. Biochem. Pharmacol. 7: 88-95. https://doi.org/10.1016/0006-2952(61)90145-9.
Farhadi, K., Esmaeilzadeh, F., Hatami, M., Forough, M., Molaie, R., 2016. Determination of phenolic compounds content and antioxidant activity in skin, pulp, seed, cane and leaf of five native grape cultivars in West Azerbaijan province, Iran. Food Chem. 199:847-855. https://doi.org/10.1016/j.foodchem.2015.12.083.

Farias, G.A., Guzman-Martinez, L., Delgado, C., Maccioni, R.B., 2014. Nutraceuticals: a novel concept in prevention and treatment of Alzheimer's disease and related disorders. J. Alzheimers Dis. 42:357-367. https://doi.org/10.3233/jad-132741.

Figueiredo-González, M., Martínez-Carballo, E., Cancho-Grande, B., Santiago, J.L., Martínez, M.C., Simal-Gándara, J., 2012a. Pattern recognition of three Vitis vinifera L. red grapes varieties based on anthocyanin and flavonol profiles, with correlations between their biosynthesis pathways. Food Chem. 130:9-19. https://doi. org/10.1016/j.foodchem.2011.06.006.

Figueiredo-González, M., Simal-Gándara, J., Boso, S., Martínez, M.C., Santiago, J.L., CanchoGrande, B., 2012b. Anthocyanins and flavonols berries from Vitis vinifera L. cv. Brancellao separately collected from two different positions within the cluster. Food Chem. 135:47-56. https://doi.org/10.1016/j.foodchem.2012.04.054.

Figueiredo-González, M., Simal-Gándara, J., Boso, S., Martínez, M.C., Santiago, J.L., CanchoGrande, B., 2012c. Flavonoids in Gran Negro berries collected from shoulders and tips within the cluster, and comparison with Brancellao and Mouratón varieties. Food Chem. 133:806-815. https://doi.org/10.1016/j.foodchem.2012.01.095.

Figueiredo-González, M., Cancho-Grande, B., Boso, S., Santiago, J.L., Martínez, M.C., SimalGándara, J., 2013. Evolution of flavonoids in Mouratón berries taken from both bunch halves. Food Chem. 138:1868-1877. https://doi.org/10.1016/j.foodchem.2012.11.083.

Gullón, B., Eibes, G., Moreira, M.T., Dávila, I., Labidi, J., Gullón, P., 2017. Antioxidant and antimicrobial activities of extracts obtained from the refining of autohydrolysis liquors of vine shoots. Ind. Crop. Prod. 107:105-113. https://doi.org/10.1016/j.indcrop.2017.05.034.

Gullón, P., Gullón, B., Dávila, I., Labidi, J., Gonzalez-Garcia, S., 2018. Comparative environmental Life Cycle Assessment of integral revalorization of vine shoots from a biorefinery perspective. Sci. Total Environ. 624:225-240. https://doi.org/10.1016/j. scitotenv.2017.12.036

Hagemann, N., Subdiaga, E., Orsetti, S., de la Rosa, J.M., Knicker, H., Schmidt, H.-P., Kappler, A., Behrens, S., 2018. Effect of biochar amendment on compost organic matter composition following aerobic composting of manure. Sci. Total Environ. 613-614: 20-29. https://doi.org/10.1016/j.scitotenv.2017.08.161.

Institute, C. A. L. S, 2012. M07-A9. 2012. Methods for Dilution Antimicrobial Susceptibility Tests for Bacteria That Grow Aerobically; Approved Standard. Wayne, PA. p. 32.

Institute, C. A. L. S, 2014. Performance Standards for Antimicrobial Susceptibility Testing; Twenty-fourth Informational Supplement. M100-S24. Wayne, PA. p. 34.

Jordão, A.M., Correia, A.C., 2012. Relationship between antioxidant capacity, proanthocyanidin and anthocyanin content during grape maturation of Touriga Nacional and Tinta Roriz grape varieties. S. Afr. J. Enol. Vitic. 33, 214-224.

Ju, Y., Zhang, A., Fang, Y., Liu, M., Zhao, X., Wang, H., Zhang, Z., 2016. Phenolic compounds and antioxidant activities of grape canes extracts from vineyards. Span. J. Agric. Res. 14:1-13. https://doi.org/10.5424/sjar/2016143-8951.

Karacabey, E., Mazza, G., 2010. Optimisation of antioxidant activity of grape cane extracts using response surface methodology. Food Chem. 119:343-348. https://doi.org/ 10.1016/j.foodchem.2009.06.029.

Karacabey, E., Mazza, G., Bayındırlı, L., Artık, N., 2012. Extraction of bioactive compounds from milled grape canes (Vitis vinifera) using a pressurized low-polarity water extractor. Food Bioprocess Technol. 5:359-371. https://doi.org/10.1007/s11947-009-0286-

Lavelli, V., Sri Harsha, P.S.C., Ferranti, P., Scarafoni, A., Iametti, S., 2016. Grape skin phenolics as inhibitors of mammalian $\alpha$-glucosidase and $\alpha$-amylase - effect of food matrix and processing on efficacy. Food Funct. 7:1655-1663. https://doi.org/10.1039/ $\mathrm{C} 6 \mathrm{FO} 00073 \mathrm{H}$

Luque-Rodríguez, J.M., Pérez-Juan, P., Luque de Castro, M.D., 2006. Extraction of polyphenols from vine shoots of Vitis vinifera by superheated ethanol-water mixtures. J. Agric. Food Chem. 54:8775-8781. https://doi.org/10.1021/jf061855j.

Max, B., Salgado, J.M., Cortés, S., Domínguez, J.M., 2010. Extraction of phenolic acids by alkaline hydrolysis from the solid residue obtained after prehydrolysis of trimming vine shoots. J. Agric. Food Chem. 58:1909-1917. https://doi.org/10.1021/jf903441d.

Moreira, M.M., Barroso, M.F., Boeykens, A., Withouck, H., Morais, S., Delerue-Matos, C., 2017. Valorization of apple tree wood residues by polyphenols extraction: comparison between conventional and microwave-assisted extraction. Ind. Crop. Prod. 104: 210-220. https://doi.org/10.1016/j.indcrop.2017.04.038.

Paz, M., Gúllon, P., Barroso, M.F., Carvalho, A.P., Domingues, V.F., Gomes, A.M., Becker, H., Longhinotti, E., Delerue-Matos, C., 2015. Brazilian fruit pulps as functional foods and additives: evaluation of bioactive compounds. Food Chem. 172:462-468. https:// doi.org/10.1016/j.foodchem.2014.09.102.

Pérez-Lamela, C., García-Falcón, M.S., Simal-Gándara, J., Orriols-Fernández, I., 2007. Influence of grape variety, vine system and enological treatments on the colour stability of young red wines. Food Chem. 101:601-606. https://doi.org/10.1016/j.foodchem.2006.02.020.

Pervin, M., Hasnat, M.A., Lee, Y.M., Kim, D.H., Jo, J.E., Lim, B.O., 2014. Antioxidant activity and acetylcholinesterase inhibition of grape skin anthocyanin (GSA). Molecules 19: 9403-9418. https://doi.org/10.3390/molecules19079403.

Plaza, M., Amigo-Benavent, M., del Castillo, M.D., Ibáñez, E., Herrero, M., 2010. Facts about the formation of new antioxidants in natural samples after subcritical water extraction. Food Res. Int. 43:2341-2348. https://doi.org/10.1016/j.foodres.2010.07.036.

Quijada-Morín, N., Regueiro, J., Simal-Gándara, J., Tomás, E., Rivas-Gonzalo, J.C., EscribanoBailón, M.T., 2012. Relationship between the sensory-determined astringency and the flavanolic composition of red wines. J. Agric. Food Chem. 60:12355-12361. https://doi.org/10.1021/jf3044346.

Rajha, H.N., Abou Jaoude, N., Louka, N., Maroun, R.G., Vorobiev, E., IEEE, 2014a. Industrial byproducts valorization through energy saving processes. Alkaline Extraction of Polyphenols From Vine Shoots. 2014 International Conference on Renewable Energies for Developing Countries (REDEC), pp. 89-94. 
Rajha, H.N., Boussetta, N., Louka, N., Maroun, R.G., Vorobiev, E., 2014b. A comparative study of physical pretreatments for the extraction of polyphenols and proteins from vine shoots. Food Res. Int. 65 (Part C):462-468. https://doi.org/10.1016/j. foodres.2014.04.024.

Rajha, H.N., Boussetta, N., Louka, N., Maroun, R.G., Vorobiev, E., 2014c. A comparative study of physical pretreatments for the extraction of polyphenols and proteins from vine shoots. Food Res. Int. 65:462-468. https://doi.org/10.1016/j.foodres.2014.04.024.

Rajha, H.N., Boussetta, N., Louka, N., Maroun, R.G., Vorobiev, E., 2015a. Electrical, mechanical, and chemical effects of high-voltage electrical discharges on the polyphenol extraction from vine shoots. Innovative Food Sci. Emerg. Technol. 31:60-66. https://doi. org/10.1016/j.ifset.2015.07.006.

Rajha, H.N., Chacar, S., Afif, C., Vorobiev, E., Louka, N., Maroun, R.G., 2015b. B-Cyclodextrin-assisted extraction of polyphenols from vine shoot cultivars. J. Agric. Food Chem. 63:3387-3393. https://doi.org/10.1021/acs.jafc.5b00672.

Rayne, S., Karacabey, E., Mazza, G., 2008. Grape cane waste as a source of transresveratrol and trans-viniferin: high-value phytochemicals with medicinal and anti-phytopathogenic applications. Ind. Crop. Prod. 27:335-340. https://doi. org/10.1016/j.indcrop.2007.11.009.

Sánchez-Gómez, R., Zalacain, A., Alonso, G.L., Salinas, M.R., 2014. Vine-shoot waste aqueous extracts for re-use in agriculture obtained by different extraction techniques: phenolic, volatile, and mineral compounds. J. Agric. Food Chem. 62:10861-10872. https://doi.org/10.1021/jf503929v.

Sánchez-Gómez, R., Zalacain, A., Alonso, G.L., Salinas, M.R., 2016. Effect of toasting on nonvolatile and volatile vine-shoots low molecular weight phenolic compounds. Food Chem. 204:499-505. https://doi.org/10.1016/j.foodchem.2016.02.137.

Senyuva, H.Z., Gokmen, V., 2007. Potential of furan formation in hazelnuts during heat treatment. Food Addit. Contam. 24 (Suppl. 1):136-142. https://doi.org/10.1080/ 02652030701315313.

Silva, L.R., Queiroz, M., 2016. Bioactive compounds of red grapes from Dão region (Portugal): evaluation of phenolic and organic profile. Asian Pac. J. Trop. Biomed. 6: 315-321. https://doi.org/10.1016/j.apjtb.2015.12.015.
Sousa, B.A., Correia, R.T.P., 2012. Phenolic content, antioxidant activity and antiamylolytic activity of extracts obtained from bioprocessed pineapple and guava wastes. Braz. J. Chem. Eng. 29, 25-30.

Srinivas, K., King, J.W., Howard, L.R., Monrad, J.K., 2010. Solubility of gallic acid, catechin, and protocatechuic acid in subcritical water from (298.75 to 415.85$) \mathrm{K}$. J. Chem. Eng. Data 55:3101-3108. https://doi.org/10.1021/je901097n.

Sukumaran, S.D., Chee, C.F., Viswanathan, G., Buckle, M.J., Othman, R., Abd Rahman, N., Chung, L.Y., 2016. Synthesis, biological evaluation and molecular modelling of 2'hydroxychalcones as acetylcholinesterase inhibitors. Molecules 21. https://doi.org/ $10.3390 /$ molecules 21070955 .

Švarc-Gajić, J., Cvetanović, A., Segura-Carretero, A., Mašković, P., Jakšić, A., 2017. Functional coffee substitute prepared from ginger by subcritical water. J. Supercrit. Fluids 128:32-38. https://doi.org/10.1016/j.supflu.2017.05.008.

Teixeira, A., Baenas, N., Dominguez-Perles, R., Barros, A., Rosa, E., Moreno, D., GarciaViguera, C., 2014. Natural bioactive compounds from winery by-products as health promoters: a review. Int. J. Mol. Sci. 15, 15638.

Thilagam, E., Parimaladevi, B., Kumarappan, C., Mandal, S.C., 2013. $\alpha$-Glucosidase and $\alpha-$ amylase inhibitory activity of Senna surattensis. J. Acupunct. Meridian Stud. 6:24-30. https://doi.org/10.1016/j.jams.2012.10.005.

Valente, M.J., Baltazar, A.F., Henrique, R., Estevinho, L., Carvalho, M., 2011. Biological activities of Portuguese propolis: protection against free radical-induced erythrocyte damage and inhibition of human renal cancer cell growth in vitro. Food Chem. Toxicol. 49: 86-92. https://doi.org/10.1016/j.fct.2010.10.001.

Vergara, C., von Baer, D., Mardones, C., Wilkens, A., Wernekinck, K., Damm, A., Macke, S. Gorena, T., Winterhalter, P., 2012. Stilbene Levels in grape cane of different cultivars in Southern Chile: determination by HPLC-DAD-MS/MS Method. J. Agric. Food Chem. 60:929-933. https://doi.org/10.1021/jf204482c.

Wine, I.O.o.V.a., 2017. Retrieved 02/09/2017 from. http://www.oiv.int/en/the-international-organisation-of-vine-and-wine. 